\title{
Cannabinoids Promote Oligodendrocyte Progenitor Survival: Involvement of Cannabinoid Receptors and Phosphatidylinositol-3 Kinase/Akt Signaling
}

\author{
Eduardo Molina-Holgado, ${ }^{1}$ José M. Vela, ${ }^{2}$ Angel Arévalo-Martín, ${ }^{1}$ Guillermina Almazán, ${ }^{3}$ \\ Francisco Molina-Holgado, ${ }^{4}$ José Borrell, ${ }^{1}$ and Carmen Guaza ${ }^{1}$ \\ ${ }^{1}$ Department of Neural Plasticity, Cajal Institute, Consejo Superior de Investigaciones Científicas, 28002 Madrid, Spain, \\ 2Department of Cellular Biology and Physiology, Histology Unit, Autònoma University of Barcelona, 08193 Bellaterra, \\ Barcelona, Spain, ${ }^{3}$ Department of Pharmacology and Therapeutics, McGill University, Montreal, Canada H3G 1H6, and \\ ${ }^{4}$ Neurology Unit, Department of Clinical Veterinary Medicine, University of Cambridge, Cambridge, United Kingdom \\ CB3 OES
}

Cannabinoids exert pleiotropic actions in the CNS, including the inhibition of inflammatory responses and the enhancement of neuronal survival after injury. Although cannabinoid receptors are distributed widely in brain, their presence has not been investigated previously in oligodendrocytes. This study examined the expression of cannabinoid type 1 (CB1) receptors in rat oligodendrocytes in vivo and in culture and explored their biological function. Expression of CB1 receptors by oligodendrocytes was demonstrated immunocytochemically in postnatal and in adult white matter as well as in oligodendrocyte cultures. Reverse transcription-PCR and Western blotting further confirmed the presence of CB1 receptors. Oligodendrocyte progenitors undergo apoptosis with the withdrawal of trophic support, as determined by TUNEL assay and caspase- 3 activation, and both the selective CB1 agonist arachidonyl-2'-chloroethylamide/(all Z)-N-(2-cycloethyl)-5,8,11,14-eicosatetraenamide (ACEA) and the nonselective cannabinoid agonists HU210 and (+)-Win-55212-2 enhanced cell survival. To investigate intracellular signaling involved in cannabinoid protection, we focused on the phosphatidylinositol-3 kinase (PI3K)/Akt pathway. HU210, (+)-Win-55212-2, and ACEA elicited a time-dependent phosphorylation of Akt. Pertussis toxin abolished Akt activation, indicating the involvement of $\mathrm{G}_{\mathrm{i}} / \mathrm{G}_{\mathrm{o}}$-protein-coupled receptors. The CB1 receptor antagonist SR141716A partially inhibited Akt phosphorylation in response to HU210 and (+)Win-55212-2 and abolished the effects of ACEA. Trophic support deprivation downregulated Akt activity, and cannabinoids recovered phospho-Akt levels. Inhibition of PI3K abrogated the survival action and the recovery of Akt activity in response to cannabinoids. SR141716A prevented only the protection conferred by ACEA. Nevertheless, SR141716A and the selective CB2 receptor antagonist SR144528 in combination inhibited the prosurvival action of HU210, which is in accordance with the finding of $\mathrm{CB} 2$ receptor expression by oligodendroglial cells. These data identify oligodendrocytes as potential targets of cannabinoid action in the CNS.

Key words: apoptosis; oligodendrocytes; Akt; glycogen synthase kinase 3 $\beta$; CB1 receptors; CB2 receptors
Synthetic and endogenous cannabinoids exert profound actions in the CNS. Thus they modulate inflammatory and immune responses (Klein et al., 2000), inhibit pain (Pertwee, 2001), and reduce neuronal damage in models of excitotoxicity (van der Stelt et al., 2001), ischemia (Nagayama et al., 1999), and traumatic brain injury (Panikashvili et al., 2001). Other studies have reported anti-proliferative properties of cannabinoids on transformed cells and the regression of malignant gliomas in experimental models (Galve-Roperh et al., 2000).

To date, three endogenous lipids, derivatives of long-chain fatty acids, have been isolated and characterized as natural ligands of cannabinoid receptors (Devane et al., 1992; Mechoulam et al., 1995; Hanus et al., 2001). Two types of cannabinoid (CB)

\footnotetext{
Received June 26, 2002; revised Aug. 26, 2002; accepted Aug. 27, 2002.

This research was funded by grants from the Ministerio de Ciencia y Tecnología of Spain (SAF-1246), from the Comunidad de Madrid (08.5/0039/98), and from the Canadian Institute of Health Research (MT-14720). We are grateful to Elisa Baides, Concha Bailón, and Carmen Hernandez for their excellent technical assistance.

Correspondence should be addressed to Dr. Eduardo Molina-Holgado, Instituto Cajal, Consejo Superior de Investigaciones Científicas, Avenida Doctor Arce 37, 28002 Madrid, Spain. E-mail: eduardomolina@cajal.csic.es.

Copyright (C) 2002 Society for Neuroscience $0270-6474 / 02 / 229742-12 \$ 15.00 / 0$
}

receptors, $\mathrm{CB} 1$ and $\mathrm{CB} 2$, have been identified (Matsuda et al., 1990; Munro et al., 1993), and recent evidence supports the existence of additional receptors (Breivogel et al., 2001; Howlett at al., 2002). CB1 receptors are concentrated in the CNS (Matsuda et al., 1993), whereas CB2 receptors are expressed in the immune system (Munro et al., 1993). CB1 receptors are present in developing and adult brain in regions involved in the control of motor coordination, memory, and cognitive processes (Herkenham et al., 1991; Mailleux and Vanderhaeghen, 1992). CB1 receptors localize in dendritic spines and axon terminals (Ong and Mackie, 1999) and modulate neuronal excitability (Huang et al., 2001). However, reports on cannabinoids in glial cells are scarce, and no studies addressing the expression and function of CB1 receptors in oligodendrocytes are presently available.

Cannabinoid receptors belong to the $\mathrm{G}_{\mathrm{i}} / \mathrm{G}_{\mathrm{o}}$-protein-coupled receptor superfamily (Pertwee, 1997). Cellular responses triggered with receptor activation include inhibition of adenylyl cyclase and voltage-gated calcium channels, increased transcription of the immediate early gene krox-24, and activation of potassium channels, mitogen-activated protein kinase (MAPK), and phosphoinositide-3 kinase (PI3K)/Akt signaling pathways (Bouaboula et al., 1995a,b; Gómez del Pulgar et al., 2000). Acti- 
vated Akt phosphorylates intracellular substrates, and this provides a survival signal that protects cells from apoptosis induced by various stresses (for review, see Brunet et al., 2001).

Survival and successful differentiation of proliferating oligodendrocyte progenitors to myelinating oligodendrocytes require contact with axons and trophic factors released by neurons and glial cells (Barres et al., 1992, 1993; Gard et al., 1995; Fernandez et al., 2000). In addition, oligodendrocytes are vulnerable to various insults, and their damage strongly affects brain function (Levine et al., 2001). Oligodendrocyte death is a prominent feature in inflammatory diseases such as multiple sclerosis (Lassmann, 1998) and other demyelinating/hypomyelinating disorders (Vela et al., 1998). However, oligodendrocyte progenitors exist in mature CNS and are recruited to the demyelinated areas where they remyelinate naked axons (Keirstead and Blakemore, 1999; Chang et al., 2000). On this basis, the identification of endogenous signals that promote oligodendrocyte progenitor survival may contribute to developing reparative strategies in demyelinating diseases. The objectives of the present study were to evaluate the expression of cannabinoid CB1 receptors in oligodendrocytes in vivo and in culture and to gain insights into the underlying physiological function of these receptors in conditions in which oligodendrocyte survival is compromised.

\section{MATERIALS AND METHODS}

Reagents. Culture media and fetal calf serum (FCS) were from Invitrogen (Barcelona, Spain). Human recombinant platelet-derived growth factor-AA (PDGF-AA) and basic fibroblast growth factor (bFGF) were from PeproTech (London, UK). The astrocytic marker anti-glial fibrillary acidic protein (GFAP) and anti- $\alpha$-tubulin were from Sigma (Madrid, Spain), and OX-42 antibody was obtained from Serotec (Oxford, England). The antibody against Akt was from Santa Cruz Biotechnology (Santa Cruz, CA). Affinity-purified rabbit antibodies against phosphoAkt $\left(\operatorname{Ser}^{473}\right)$, phospho-GSK-3 $\beta\left(\operatorname{Ser}^{9}\right)$, and cleaved caspase-3 were from Cell Signaling Technology (Beverly, MA). Monoclonal anti-glycogen synthase kinase- $3 \beta$ (GSK-3 $\beta$ ) was from BD Transduction Laboratories (San Diego, CA). The affinity-purified polyclonal anti-CB1 receptor antibody was obtained from Calbiochem (Darmstadt, Germany), and the CB2 receptor antibody was from Cayman Chemical (Ann Arbor, $\mathrm{MI}$ ). The oligodendrocyte antibody anti-myelin basic protein (MBP) was from Sternberger Monoclonals (Lutherville, MD), and the antioligodendrocyte monoclonal antibody (RIP clone) was from Chemicon (Temecula, CA). The secondary peroxidase-conjugated anti-mouse or anti-rabbit antibodies were from Bio-Rad (Hercules, CA) and Jackson ImmunoResearch Laboratories (West Grove, PA), respectively. The secondary antibodies for immunofluorescence anti-rabbit IgG-Alexa 594 or 488 and anti-mouse IgG-Alexa 488 or 594 were from Molecular Probes (Eugene, OR), the biotinylated anti-rabbit IgG was from Amersham Biosciences (Barcelona, Spain), and the avidin-peroxidase was from Dako (Barcelona, Spain). The cannabinoids $(+)$ Win 55,212-2 and arachidonyl-2'-chloroethylamide/(all Z)- $N$-(2-cycloethyl)-5,8,11,14-eicosatetraenamide (ACEA) and the PI3K inhibitors LY294002 and wortmannin were from Tocris Cookson (Bristol, UK). HU210 was a generous gift from Professor Raphael Mechoulam (Hebrew University, Jerusalem, Israel). All other reagents were obtained from standard suppliers.

Tissue processing and immunohistochemistry. Animals used in this study were postnatal (P0, P5, P9, P15) and adult (90 d old) rats of the Wistar strain, three per group. All efforts were made to minimize animal suffering, and experimental animal procedures were conducted in compliance with Spanish legislation and according to the European Union directives on this subject (86/609/EEC).

Animals were anesthetized with sodium pentobarbital $(50 \mathrm{mg} / \mathrm{kg}$ body weight) and transcardially perfused with $4 \%$ paraformaldehyde in $0.1 \mathrm{M}$ phosphate buffer (PB). Brains were dissected out and immersed for an additional $4 \mathrm{hr}$ at room temperature (RT) in the same fixative. Then brains were washed in PB and sliced in $40-\mu \mathrm{m}$-thick coronal sections with a vibratome. Tissue sections were rinsed $3 \times 5 \mathrm{~min}$ in TBS $(50 \mathrm{~mm}$ Tris- $\mathrm{HCl}$ containing $150 \mathrm{~mm} \mathrm{NaCl}$ ), $\mathrm{pH} 7.4$, treated for 10 min with $2 \%$ hydrogen peroxide in $100 \%$ methanol to block endogenous peroxidase, and rinsed again $3 \times 5 \mathrm{~min}$ in TBS with $0.1 \%$ Triton X-100 (TBS-T).
Sections then were placed for $30 \mathrm{~min}$ at RT in blocking buffer (BB; TBS-T containing $10 \%$ FCS) and incubated overnight at $4^{\circ} \mathrm{C}$ with a rabbit anti-CB1 receptor antibody raised against the N-terminal 14 amino acids of the rat CB1 receptor (1:1000 in BB). After being rinsed $3 \times 5 \mathrm{~min}$ in TBS-T, the sections were incubated for $60 \mathrm{~min}$ at RT with anti-rabbit IgG-biotinylated secondary antibody (1:200 in BB), rinsed again, and incubated for $60 \mathrm{~min}$ at RT with avidin-peroxidase (1:400 in $\mathrm{BB})$. After rinsing, the peroxidase reaction was visualized by transferring the sections to $100 \mathrm{ml}$ of TBS containing $50 \mathrm{mg}$ of 3,3'-diaminobenzidine$4 \mathrm{HCl}(\mathrm{DAB})$ and $33 \mu \mathrm{l}$ of hydrogen peroxide for $5 \mathrm{~min}$. Finally, the sections were rinsed, mounted on gelatin-coated slides, dehydrated in graded ethanol, cleared in xylene, and coverslipped in DPX. As a negative control for immunocytochemical staining, the primary antibody was omitted in some sections per animal for each age.

Simultaneous visualization of CB1 receptor expression and oligodendrocytes was achieved by double immunofluorescence that combined the $\mathrm{CB} 1$ receptor antibody and RIP, an anti-oligodendrocyte-specific antibody. Vibratome sections were immunostained for the CB1 receptor as described previously but with the use of a 1:1000 dilution of Alexa Fluor 594-conjugated anti-rabbit IgG as a secondary antibody. After being rinsed, the sections were incubated overnight at $4^{\circ} \mathrm{C}$ with RIP $(1: 100,000$ in $\mathrm{BB}$ ), rinsed again, and incubated with the secondary Alexa Fluor 488-conjugated anti-mouse $\operatorname{IgG}(1: 1000)$. Finally, the sections were rinsed, mounted on gelatin-coated slides, and coverslipped in fluorescent mounting medium (Shandon-Lipshaw, Pittsburgh, PA). As a negative control, primary antibodies were omitted. Sections were analyzed by confocal laser microscopy.

Purification and culture of oligodendrocyte progenitors. Primary mix glial cultures were prepared as described previously (Almazan et al., 1993; Molina-Holgado et al., 2001) according to the modified technique of McCarthy and de Vellis (1980). Briefly, forebrains of newborn Wistar rats were dissociated mechanically, filtered through a $150 \mu \mathrm{m}$ nylon mesh, resuspended in DMEM containing $12 \%$ heat-inactivated FCS, and plated on poly-L-ornithine-coated $(15 \mu \mathrm{g} / \mathrm{ml}) 75 \mathrm{~cm}^{2}$ flasks (Nunc, Wiesbaden, Germany). After $10 \mathrm{~d}$ in culture the flasks were shaken at $225 \mathrm{rpm}$ at $37^{\circ} \mathrm{C}$ for $3 \mathrm{hr}$ to remove loosely adherent microglia. The supernatant was plated on bacterial grade Petri dishes for $2 \mathrm{hr}$, and the adherent microglial cells were detached and replated onto uncoated tissue culture dishes to obtain a $>98 \%$ pure microglial culture according to OX-42 staining. The remaining oligodendrocyte progenitors present on the top of the confluent monolayer of astrocytes were dislodged by shaking overnight at $260 \mathrm{rpm}$. The cell suspension was filtered through a $10 \mu \mathrm{m}$ nylon mesh and then preplated on bacterial grade Petri dishes for $2 \mathrm{hr}$. The nonadherent oligodendrocyte progenitors that remained in suspension were recovered and plated again on bacterial grade Petri dishes for $1 \mathrm{hr}$. The resulting enriched oligodendrocyte progenitor cell suspension was plated onto poly-D-lysine-coated (PDL; $5 \mu \mathrm{g} / \mathrm{ml})$ six-well $\left(9.6 \mathrm{~cm}^{2} /\right.$ well) and 24-well $\left(2 \mathrm{~cm}^{2} /\right.$ well $)$ tissue culture dishes and glass coverslips at a density of $25 \times 10^{3}$ cells $/ \mathrm{cm}^{2}$ and cultured for $2 \mathrm{~d}$ before experiments in serum-free defined medium (SFM) containing $5 \mathrm{ng} / \mathrm{ml}$ PDGF-AA plus $5 \mathrm{ng} / \mathrm{ml}$ bFGF. The SFM used in oligodendroglial cultures consisted of DMEM supplemented with (in nM) 30 triiodothyronine, 20 hydrocortisone, 20 progesterone, 10 D-biotin, and 30 selenium, plus $25 \mu \mathrm{g} / \mathrm{ml}$ apo-transferrin, $10 \mu \mathrm{g} / \mathrm{ml}$ insulin, $1 \mu \mathrm{g} / \mathrm{ml}$ putrescine, $0.1 \%$ BSA, 50 $\mathrm{U} / \mathrm{ml}$ penicillin, and $50 \mathrm{U} / \mathrm{ml}$ streptomycin. To promote the differentiation of oligodendrocyte progenitors to MBP-positive oligodendrocytes, we switched the cultures to SFM without mitogenic growth factors for an additional $5 \mathrm{~d}$. The purity of oligodendroglial cultures was assessed by examining the characteristic cell morphologies under phase-contrast microscopy and was confirmed by immunostaining with antibodies against oligodendroglial cell-specific markers as described below. After $2 \mathrm{~d}$ in culture the A2B5-positive oligodendrocyte progenitors represented $98 \pm 2 \%$ of total cells (means $\pm \mathrm{SEM} ; n=10$ independent cultures; two coverslips per culture, five microscopic field per coverslip; total cells counted, 26,300). In cultures that were differentiated for $5 \mathrm{~d}, 96.5 \pm 0.5 \%$ of the total cells were MBP-positive ( $n=10$ cultures; total cells counted, $18,343)$. Astrocyte cultures, $>99 \%$ glial fibrillary acidic protein (GFAP)positive cells, were obtained after removing the oligodendrocyte progenitors present on the top of the astrocyte monolayer by extensive shaking; cultures were trypsinized and replated in tissue culture six-well dishes for an additional $3 \mathrm{~d}$ to obtain total RNA and protein extracts.

Immunocytochemistry in cultured cells. For immunostaining of oligodendrocyte progenitors and microglial surface antigens, live cells plated onto PDL-coated coverslips were incubated for $15 \mathrm{~min}$ at RT with the 

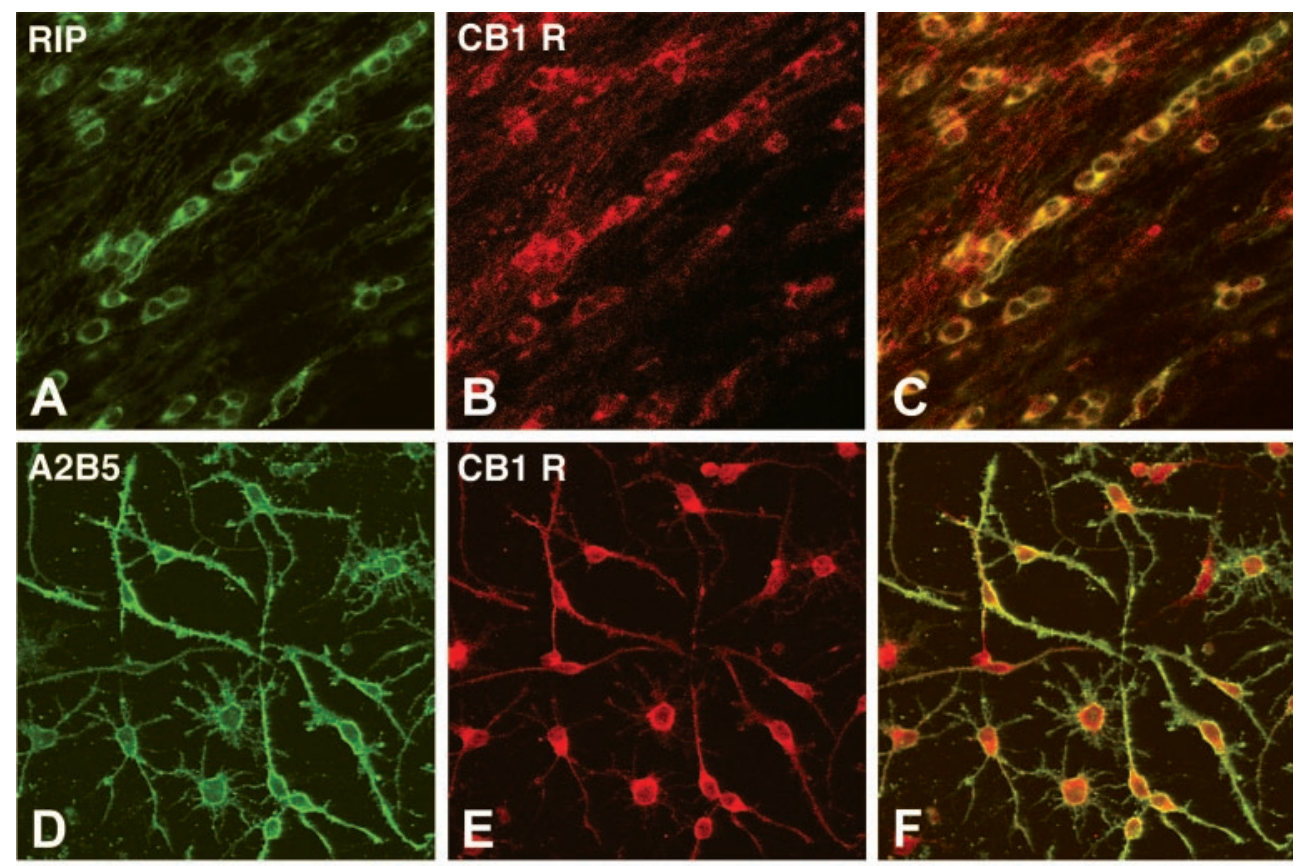

Figure 1. Oligodendroglial cells express CB1 receptors in vivo and in culture. Shown is double immunostaining with the oligodendrocyte monoclonal antibody RIP ( $A$, green $)$ and anti-CB1 receptor $(B$, red) in $\mathrm{P} 9$ rat corpus callosum. Also shown is double immunocytochemistry of cultured oligodendrocyte progenitors with A2B5 (D, green) and anti-CB1 receptor $(E, r e d)$. Differentiated oligodendrocytes were double labeled with anti-MBP $(G$ green $)$ and anti-CB1 receptor $(H, r e d)$. $C$, $F, I, L, O$, Overlays of oligodendroglial markers and $\mathrm{CB} 1$ receptors. Magnifications show an oligodendrocyte progenitor $(J-L)$ and a differentiated oligodendrocyte $(M-O)$ expressing CB1 receptors in culture. Scale bars, $A-C, 50 \mu \mathrm{m} ; D-I, 40$ $\mu \mathrm{m} ; J-O, 20 \mu \mathrm{m}$.
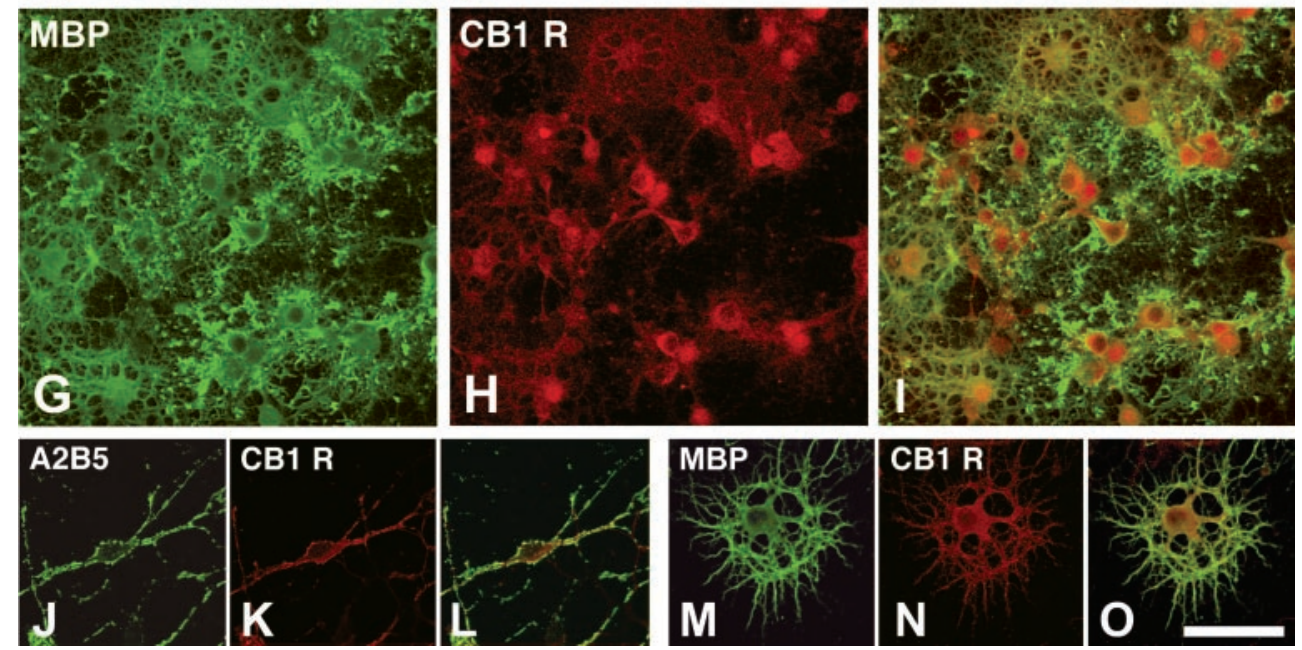

mouse monoclonal antibodies A2B5 (culture supernatants diluted 1:10) or OX-42 (1:200). After being rinsed with PBS, the cells were incubated for $15 \mathrm{~min}$ at RT with secondary Alexa-conjugated (Alexa 488 or Alexa 594) anti-mouse IgM or IgG. Then the coverslips were washed with PBS, fixed with $4 \%$ paraformaldehyde, and mounted on slides or processed for double labeling. For cleaved (active) caspase-3, MBP, GFAP, CB1, and $\mathrm{CB} 2$ receptor immunocy tochemistry, the fixed cells were incubated overnight at $4^{\circ} \mathrm{C}$ with anti-MBP (1:5000), anti-GFAP (1:1000), anti-CB1 (1:1500), anti-CB2 (1:2000), or anti-cleaved caspase-3 (1:200) diluted in PBS containing $5 \%$ FCS and $0.1 \%$ Triton X-100. Coverslips then were rinsed and incubated for $2 \mathrm{hr}$ at RT with 1:1500 anti-rabbit or anti-mouse IgGs conjugated with Alexa 488 or Alexa 594. Nonspecific interactions of secondary antibodies were verified by omitting the primary antibodies. The nuclei were labeled with bis-benzimide (Hoechst 33258; $1 \mu \mathrm{g} / \mathrm{ml}$ for 10 min at RT). Double labeling combining A2B5/CB1, A2B5/CB2, A2B5/ OX42, A2B5/GFAP, A2B5/caspase-3, MBP/CB1, and MBP/CB2 was performed by a combination of the described technical procedures. Coverslips were mounted on glass slides with fluorescent mounting medium. For cell counting the preparations were visualized under a Zeiss Axiovert (Oberkochen, Germany) fluorescent microscope with a $40 \times$ objective. At least three independent cultures were examined for each antibody; five microscopic fields were counted per coverslip and two coverslips per culture.

Withdrawal of trophic support and cell viability experiments. Oligodendrocyte progenitors grown for $2 \mathrm{~d}$ in serum-free defined medium plus 5 ng/ml PDGF/bFGF (controls) were switched overnight (12 hr) or in DMEM/F12 with or without cannabinoids. After such treatment the oligodendrocyte progenitor survival was quantified by the 3-(4,5dimethylthiazol-2-yl)-2,5-diphenyltetrazolium bromide (MTT) assay and by lactate dehydrogenase (LDH) activity released from damaged cells. The MTT reaction is based on the cleavage of the tetrazolium ring by active mitochondria of viable cells into a dark blue formazan product. MTT was dissolved in PBS and used at a concentration of $0.5 \mathrm{mg} / \mathrm{ml}$. After $2 \mathrm{hr}$ of incubation at $37^{\circ} \mathrm{C}$, acidic isopropanol was added to dissolve the formazan crystals, and the absorbance was read at $595 \mathrm{~nm}$. Data are presented as a percentage relative to their corresponding controls. The release of LDH into the culture supernatant representing cell lysis was assessed with a commercial LDH kit (Roche Molecular Biochemicals, Mannheim, Germany). LDH values were calculated relative to total LDH content measured after the cells were lysed completely by $1 \%$ Triton $\mathrm{X}-100$. In addition, the percentage of surviving oligodendrocyte progenitors in the presence or absence of cannabinoids was established by counting A2B5-positive progenitors; the results were expressed over the total nuclei stained with bis-benzimide.

Apoptosis of oligodendrocyte progenitors was measured by nuclear DNA staining, TUNEL assay, and caspase-3 immunocytochemistry. Morphological changes in the nuclear chromatin of oligodendrocyte progenitors undergoing apoptosis was detected by staining with bisbenzimide $(1 \mu \mathrm{g} / \mathrm{ml})$, and the number of pyknotic nuclei was determined by examination on a fluorescence microscope. Apoptotic nuclei also were 
A
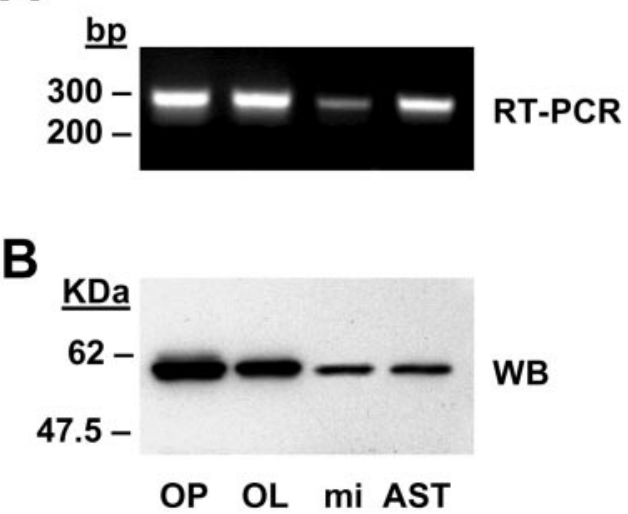

Figure 2. Expression of cannabinoid CB1 receptor in cultured brain glial cells. $A$, Total RNA was extracted from purified cultures of oligodendrocyte progenitors, differentiated oligodendrocytes, microglial cells, and astrocytes. RT-PCR amplification was performed with specific CB1 primers that used $2 \mu \mathrm{g}$ of RNA, as described in Materials and Methods. $B$, The expression of CB1 receptor protein also was demonstrated by Western blot analysis (anti-CB1 diluted to 1:1500) of whole-cell lysates $(25 \mu \mathrm{g}$ of protein). CB1 mRNA and protein levels in progenitors and differentiated oligodendrocytes appeared relatively higher than in microglia and astrocytes. $O P$, Oligodendrocyte progenitors; $O L$, differentiated oligodendrocytes; mi, microglia; $A S T$, astrocytes.

detected by using the terminal deoxynucleotidyl transferase dUTP nick end labeling (TUNEL) technique. Oligodendrocyte progenitors were stained with A2B5 antibody, fixed with 4\% paraformaldehyde in PBS for $30 \mathrm{~min}$ at RT, and permeabilized with $0.1 \%$ Triton X-100 and $0.1 \%$ sodium citrate for $2 \mathrm{~min}$ on ice. After washing, in situ labeling of nuclear DNA fragmentation was performed as described previously (MolinaHolgado et al., 2001). Coverslips were washed two times in PBS and fixed with $4 \%$ paraformaldehyde in PBS for $30 \mathrm{~min}$ at RT. Cells were rinsed, treated with $0.1 \%$ Triton $\mathrm{X}-100$ in $0.1 \%$ sodium citrate, and rinsed again with PBS. Cells then were transferred for $10 \mathrm{~min}$ to a reaction buffer (30 mM Tris- $\mathrm{HCl}, 140 \mathrm{~mm}$ sodium cacodylate, $1 \mathrm{~mm}$ cobalt chloride), $\mathrm{pH} 7.2$, and incubated for $45 \mathrm{~min}$ at $37^{\circ} \mathrm{C}$ in a reaction buffer containing $0.3 \mathrm{U} / \mu \mathrm{l}$ terminal deoxynucleotidyl transferase and $20 \mu \mathrm{M}$ biotinylated 16-dUTP. After being rinsed, the cells were incubated for $60 \mathrm{~min}$ at RT with a 1:500 dilution of avidin that was conjugated with fluorescein, rinsed, and mounted on slides. The viable oligodendrocyte progenitors were quantified by counting condensed bis-benzimide nuclei and TUNEL- and caspase-positive cells; the results are expressed as percentage of the total cells determined by bis-benzimide labeling.

Western blot analysis. After treatments the oligodendrocyte progenitors were washed with ice-cold PBS and lysed in $60 \mu \mathrm{l}$ of TBS, $\mathrm{pH}$ 7.6, containing $10 \%$ glycerol, $1 \%$ Nonidet P-40, and (in mM) 1 EDTA, 1 EGTA, 1 PMSF, 5 benzamidine, 1 sodium orthovanadate, $2 \mathrm{NaF}$, and 5 DTT plus $50 \mu \mathrm{g} / \mathrm{ml}$ leupeptin and $10 \mu \mathrm{g} / \mathrm{ml}$ aprotinin. Cell lysates were mixed with $5 \times$ Laemmli sample buffer and boiled for $4 \mathrm{~min}$. Then equal amounts of protein $(25 \mu \mathrm{g})$ were resolved on $10 \%$ SDS-PAGE and electroblotted for $1 \mathrm{hr}$ at $4^{\circ} \mathrm{C}$ to nitrocellulose (Amersham Biosciences). The membranes were blocked for $1 \mathrm{hr}$ at RT in $5 \%(\mathrm{w} / \mathrm{v})$ dry skim milk (Sveltese, Nestlé, Barcelona, Spain) in TBS plus $0.1 \%$ Tween 20 (TBST); then the blots were rinsed in TBST. The membranes were incubated overnight with anti-phospho (Ser $\left.{ }^{473}\right)$ Akt (1:1000), anti-Akt (1:4000), anti-GSK-3 $\beta$ (1:3000), or anti-phospho (Ser $\left.{ }^{9}\right)$ GSK-3 $\beta$ (1:1000). After extensive washing in 5\% milk-TBST solution, the blots were incubated with peroxidase-conjugated anti-rabbit $(1: 15,000)$ or anti-mouse $(1: 8000)$ secondary antibodies for $1 \mathrm{hr}$ at RT. Finally, the blots were rinsed, and the peroxidase reaction was developed by enhanced chemiluminescence (Amersham Biosciences). The blots were stripped in $62.5 \mathrm{~mm}$ Tris- $\mathrm{HCl}$, $\mathrm{pH}$ 6.8, containing $2 \%$ SDS and $0.7 \% \beta$-mercaptoethanol and were reprobed sequentially.

Reverse transcriptase-PCR analysis. Cells grown in $9.6 \mathrm{~cm}^{2}$ dishes were washed twice with PBS, and total RNA was isolated by the guanidium isothiocyanate/phenol/chloroform method. RNA was quantified spectrophotometrically and treated with DNase to digest any contaminating genomic DNA. RT-PCR was performed in one step by using the Titan one-tube RT-PCR system according to the manufacturer's instructions (Roche Molecular Biochemicals) with $2 \mu \mathrm{g}$ of RNA. The CB1 receptor primers were 5'-TATATTCTCTGGAAGGCTCACAGCC and 5'GAGCATACTGCAGAATGCAAACACC (Bouaboula et al., 1995a). Reactions were performed in a thermal cycler, with $50^{\circ} \mathrm{C}$ reverse transcription for $30 \mathrm{~min}$, and the following PCR amplification steps: $94^{\circ} \mathrm{C}$ denaturation for $30 \mathrm{sec}, 64^{\circ} \mathrm{C}$ primer annealing for $30 \mathrm{sec}$, and $68^{\circ} \mathrm{C}$ elongation for $40 \mathrm{sec}$ for 25 cycles (Molina-Holgado et al., 2002). The PCR products were resolved on $2 \%$ agarose gels containing ethidium bromide; the CB1 transcript was identified as a 270 bp band. Glyceraldehyde-3 phosphate dehydrogenase (GAPDH) was used as an internal standard (data not shown). As a control for DNA contamination, PCR was performed on each sample, omitting the reverse transcriptase step.

Statistical analysis. Results are presented as the means \pm SEM of at least three different experiments performed in separate cell preparations; duplicate or triplicate determinations were performed in each experiment. One-way ANOVA, followed by a posteriori Tukey's multiple comparison test was used to examine the statistical significance; $p$ values $<0.05$ were considered significant.

\section{RESULTS}

\section{Cannabinoid CB1 receptors are expressed by oligodendrocytes in vivo and in culture}

In the adult CNS, CB1 receptor immunoreactivity is concentrated mostly in afferent axon terminals around neuronal surfaces as well as on neuronal cell bodies and dendrites in different brain areas (Ong and Mackie, 1999). However, the presence of CB1 receptors is not restricted to neurons, because we found a moderate-to-weak immunostaining in white matter areas. Cells tended to be arranged in rows, and on the basis of double immunocytochemistry they were identified as oligodendroglial cells (Fig. $1 A-C$ ). All of the different developmental stages, that is, progenitors found at early postnatal times, differentiating oligodendrocytes found by the second postnatal week, and differen-

Table 1. Effect of cannabinoids on oligodendrocyte progenitor survival after deprivation of trophic support

\begin{tabular}{|c|c|c|c|c|c|c|}
\hline Treatment & $\begin{array}{l}\text { A2B5 }{ }^{+} \text {cells } \\
\text { (\% of control) }\end{array}$ & $\begin{array}{l}\text { MTT assay } \\
\text { (\% of control) }\end{array}$ & $\begin{array}{l}\text { LDH release } \\
\text { (\% of total) }\end{array}$ & $\begin{array}{l}\text { TUNEL }^{+} \text {cells } \\
\text { (\% of total) }\end{array}$ & $\begin{array}{l}\text { Condensed nuclei } \\
(\% \text { of total })\end{array}$ & $\begin{array}{l}\text { Caspase- } 3^{+} \text {cells } \\
(\% \text { of total })\end{array}$ \\
\hline CTL (PDGF + bFGF) & $100 \pm 2.6$ & $100 \pm 3.5$ & $3.33 \pm 0.8$ & $2.18 \pm 0.2$ & $1.3 \pm 0.6$ & $1.67 \pm 0.6$ \\
\hline DMEM + F12 (DF) & $53.6 \pm 5.1^{*}$ & $56.3 \pm 1.2^{*}$ & $34.3 \pm 5.8^{*}$ & $23.7 \pm 1.5^{*}$ & $18.0 \pm 1.6^{*}$ & $20.2 \pm 1.8^{*}$ \\
\hline $\mathrm{DF}+\mathrm{HU} 210$ & $80.4 \pm 5.7^{\Delta}$ & $80.3 \pm 2.6^{\#}$ & $8.00 \pm 1.0^{\#}$ & $3.70 \pm 0.3^{\#}$ & $2.30 \pm 0.3^{\#}$ & $2.36 \pm 0.3^{\#}$ \\
\hline $\mathrm{DF}+$ Win $55212-2$ & $83.0 \pm 6.4^{\Delta}$ & $86.3 \pm 2.2^{\#}$ & $10.6 \pm 0.8^{\#}$ & $4.40 \pm 0.4^{\#}$ & $3.20 \pm 0.3^{\#}$ & $1.78 \pm 0.4^{\#}$ \\
\hline
\end{tabular}

Oligodendrocyte progenitors were cultured for $2 \mathrm{~d}$ in serum-free defined medium plus $5 \mathrm{ng} / \mathrm{ml}$ of both PDGF and bFGF and then switched to DMEM/F12 (DF) medium alone without growth supplements for $12 \mathrm{hr}$ in the presence or absence of the nonselective cannabinoid agonists HU210 (500 nM) or (+)-Win 55212-2 (25 nM). The MTT and LDH data are the mean \pm SEM of four independent experiments performed in triplicate. Quantification of condensed nuclei, A2B5-, TUNEL-, and caspase-3-positive cells was obtained from at least eight coverslips (5 microscopic fields/coverslip), and results are the mean \pm SEM of four independent cultures. A minimum of 1500 cells was counted per coverslip. Statistical differences: ${ }^{*} p<0.001$ DMEM + F12 (DF) versus control cells (with PDGF and bFGF); ${ }^{*} p<0.001$ DF + HU210 or DF + Win55212-2 versus DF; $\Delta_{p}<0.01 \mathrm{DF}+\mathrm{HU} 210$ or DF + Win55212-2 versus DF. 
Figure 3. Cannabinoids protect oligodendrocyte progenitors from apoptosis induced by withdrawal of trophic support $A$, Phase-contrast images of live cells showing the effects of HU210 $(500 \mathrm{~nm})$ or (+)-Win 55,212-2 (25 nM) on cultures deprived of trophic support. $B$, Photomicrographs showing the reduction of TUNEL $^{+}$(green) oligodendrocyte progenitors $\left(\mathrm{A} 2 \mathrm{~B} 5{ }^{+} ; \mathrm{red}\right)$ in cultures deprived of trophic support and treated with HU210 or (+)-Win 55,212-2. C, Immunoreactivity of active caspase- 3 (red) in oligodendrocyte progenitors $\left(\mathrm{A} 2 \mathrm{~B} 5^{+} ;\right.$green $)$ deprived of trophic support and treated with HU210 and (+)-Win 55,212-2. D, E, Arrows indicate oligodendrocyte progenitors $\left(\mathrm{A} 2 \mathrm{~B}^{+}{ }^{+}\right.$; red or green) that display condensed chromatin (bis-benzimide ${ }^{+}$; blue), DNA fragmentation (TUNEL ${ }^{+}$; green), or active caspase-3 immunostaining (red). Scale bars: $A-C, 50 \mu \mathrm{m} ; D, E, 10 \mu \mathrm{m}$.
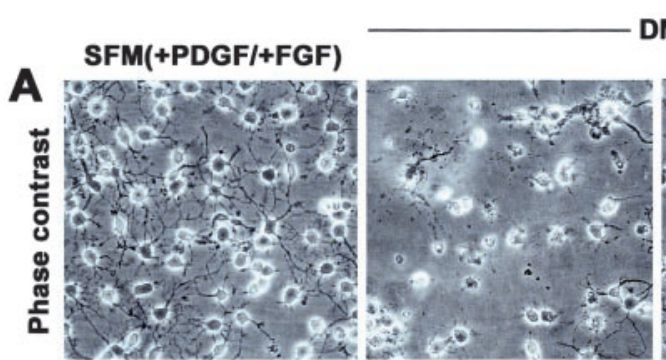

DMEM:F-12(-PDGFI-FGF)

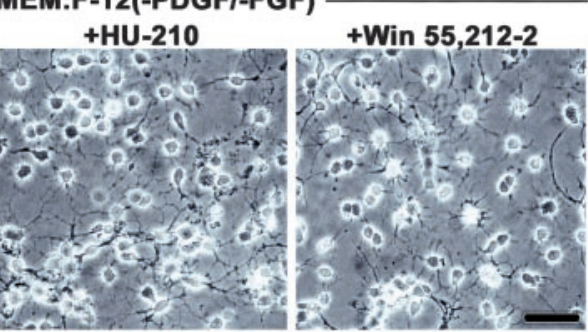

B
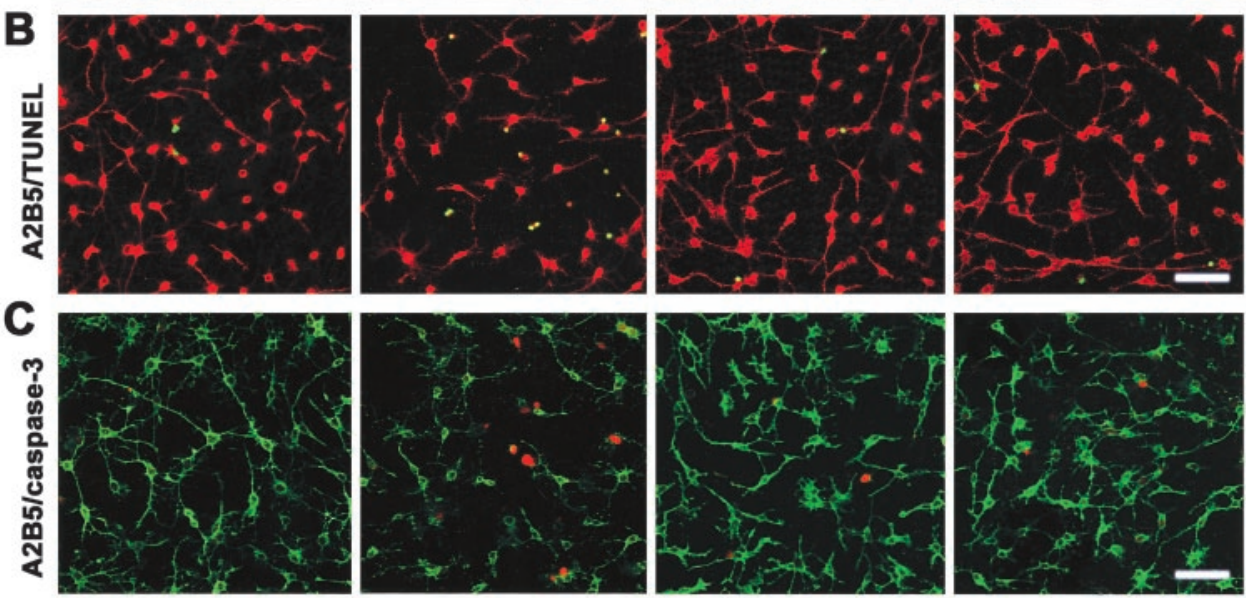

D

A2B5 Hoechst 33258 TUNEL
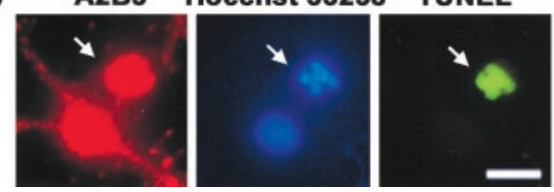

$\mathbf{E}$
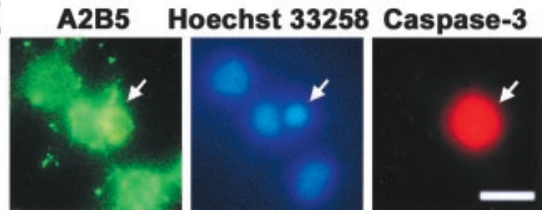

tiated oligodendrocytes in the adult, expressed CB1 receptors (data not shown). Oligodendroglial were the cells showing the highest immunoreactivity in white matter at all of the ages that were analyzed; however, we cannot rule out the possibility that other glial cells might express CB1 receptors in vivo.

The expression of $\mathrm{CB} 1$ receptors in cultured progenitors and differentiated oligodendrocytes was investigated by immunocytochemistry, Western blotting, and RT-PCR. Results from doubleimmunofluorescent labeling revealed that both A2B5-positive oligodendrocyte progenitors and MBP-positive differentiated oligodendrocytes expressed CB1 receptors (Fig. 1D-I). RT-PCR analysis that used specific $\mathrm{CB} 1$ oligonucleotide primers (Bouaboula et al., 1995a) showed an 270 bp band, as expected (Fig. 2A), in progenitor and differentiated oligodendrocytes. Similarly, expression of CB1 receptor protein was detected by Western blot analysis in progenitor and differentiated cultures (Fig. $2 B$ ). This was evidenced by the presence of a prominent immunostained band with a molecular mass of $\sim 55 \mathrm{kDa}$, consistent with other reports (Matsuda et al., 1990). RNA and protein also were isolated from microglial and astroglial cultures to compare the expression levels of CB1 receptors among the different glial cells. Samples were processed simultaneously, and the experimental conditions for the Western blot and RT-PCR were strictly maintained. Our results, in line with the in vivo observations, revealed that oligodendrocyte progenitors and differentiated oligodendrocytes expressed relatively higher levels of brain cannabinoid receptor mRNA and protein than microglia and astrocytes (Fig. 2).

\section{Cannabinoids protect oligodendrocyte progenitors from apoptosis}

To assess the effect of cannabinoids on oligodendrocyte progenitor survival, we cultured cells for $2 \mathrm{~d}$ in serum-free defined medium plus $5 \mathrm{ng} / \mathrm{ml}$ of PDGF and FGF and then switched to DMEM/F12 medium alone without growth supplements for 12 $\mathrm{hr}$ in the presence or absence of the nonselective cannabinoid agonists HU210 (500 nM) or (+)-Win 55212-2 (25 nM). Withdrawal of trophic support resulted in a marked reduction of oligodendrocyte progenitor viability, as evidenced by cell counting of A2B5-positive progenitors, MTT assay, and LDH release to the culture media. As shown in Table 1, the decreased survival measured by MTT assay and cell counting ( $\sim 40 \%)$ was in close agreement with the increased LDH activity in the media of deprived cultures. Interestingly, trophic deprivation-mediated cell death was prevented significantly when oligodendrocyte progenitors were treated with the cannabinoid agonists HU210 or (+)-Win 55212-2. Cannabinoids increased MTT values and the number of surviving A2B5-positive oligodendrocyte progenitors by $\sim 50 \%$ while they decreased $\mathrm{LDH}$ release (Table 1 ).

Cell death was characterized morphologically by a loss of cell processes and a shrinkage of the cell body (Fig. 3). The presence in the culture supernatants of cellular debris and shrunken dead cells detached from the substrate paralleled the reduction in cell numbers and was consistent with the increased LDH activity in the culture media. To characterize further the oligodendrocyte progenitor death in our experimental paradigm, we performed 


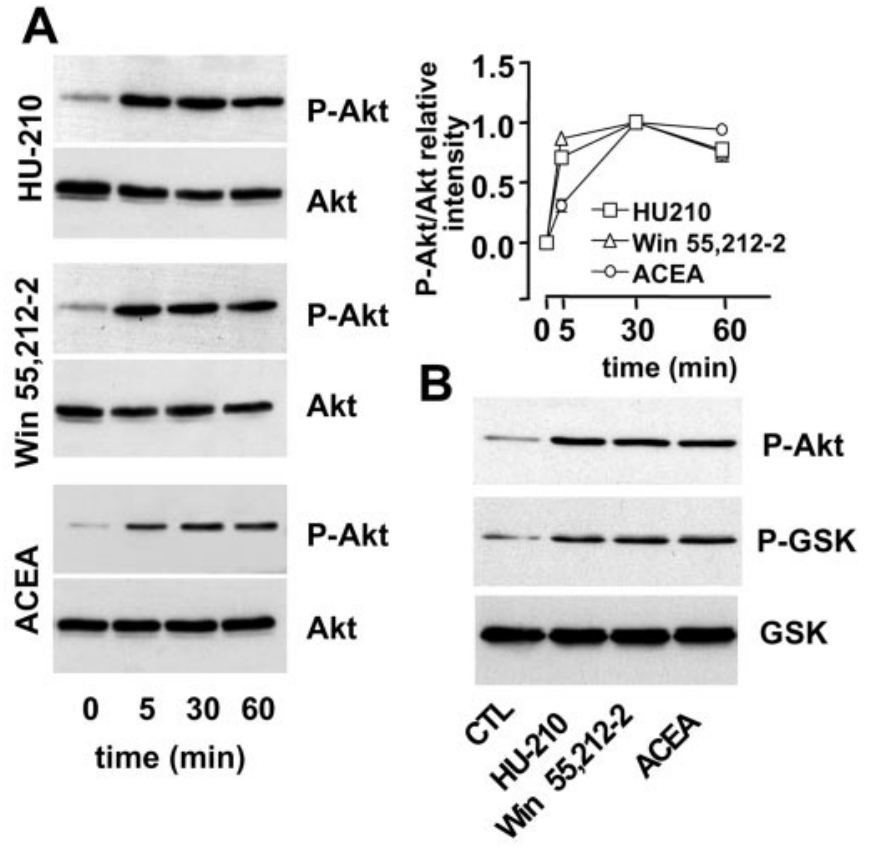

Figure 4. Cannabinoids produce a time-dependent phosphorylation of Akt and GSK-3 $\beta$. Oligodendrocyte progenitors were stimulated with cannabinoid agonists in DMEM containing $1 \%$ FCS for different time periods: 5, 30, and $60 \mathrm{~min}(A)$ or $10 \mathrm{~min}(B)$. Western blot analysis was performed with antibodies specific for phospho-Akt $\left(\mathrm{Ser}^{473}\right)$ and phospho-GSK-3 $\beta\left(\operatorname{Ser}^{9}\right)$. The antibodies were stripped off, and the membranes were reprobed with antibodies recognizing the total antigen (phosphorylated and unphosphorylated). Immunoblots in $A$ also were analyzed by densitometry (top right); the values are expressed as the means \pm SEM of three independent experiments performed in duplicate.

nuclear Hoechst 33258 staining and TUNEL to detect chromatin condensation and DNA fragmentation, respectively. Figure 3, $B$ and $D$, shows that trophic deprivation induced the appearance of TUNEL-positive oligodendrocyte progenitors displaying morphological signs of apoptosis: nuclear condensation and fragmentation (karyorhexis). Approximately $20 \%$ of oligodendrocyte progenitors were TUNEL-positive after $12 \mathrm{hr}$ of trophic support deprivation, whereas $<5 \%$ of cells showed DNA fragmentation in the presence of HU210 or (+)-Win 55212-2 (Table 1). Because the TUNEL method does not distinguish unambiguously between apoptosis and necrosis, we investigated caspase-3 expression by immunocytochemistry. Cleavage of pro-caspase 3 to an active $17 \mathrm{kDa}$ protease has been implicated in the execution of oligodendrocyte apoptosis (Gu et al., 1999). Colocalization of the active form of caspase-3 (17 kDa) and A2B5 was found in starved cultures, particularly on cells exhibiting nuclear condensation (Fig. 3C,E). In line with the above results, HU210 and (+)-Win 55212-2 significantly reduced caspase-3 immunoreactivity after trophic support deprivation (Table 1; Fig. 3C). Therefore, these results indicate that oligodendrocyte progenitors are highly vulnerable to trophic factor deprivation and that cannabinoids protect progenitor cells from the apoptosis induced by such a deprivation.

\section{Cannabinoids induce Akt activation in oligodendrocyte progenitors via a $\mathbf{G}_{\mathbf{i}} / \mathbf{G}_{\mathrm{o}}$-protein- and PI3K-dependent pathways}

We next investigated whether cannabinoids activate the serine/ threonine kinase Akt, because this pathway has been implicated
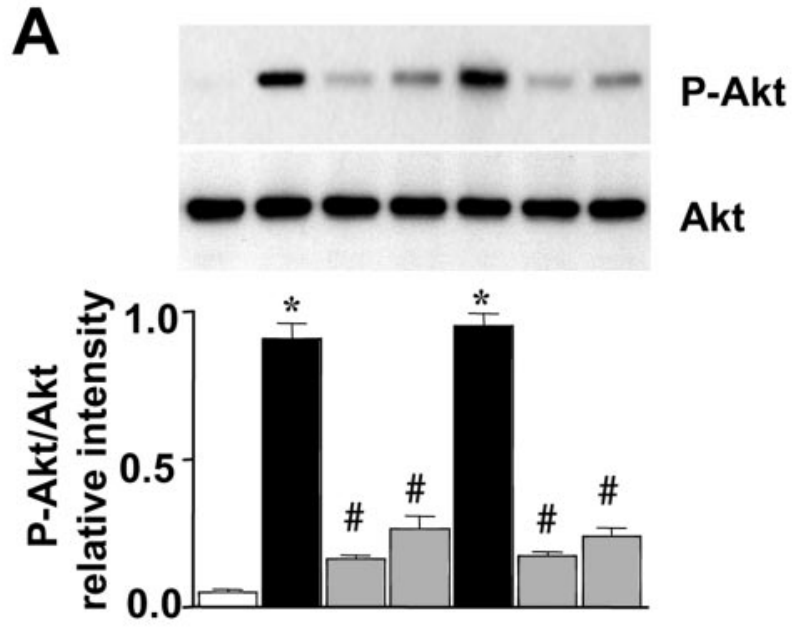

B
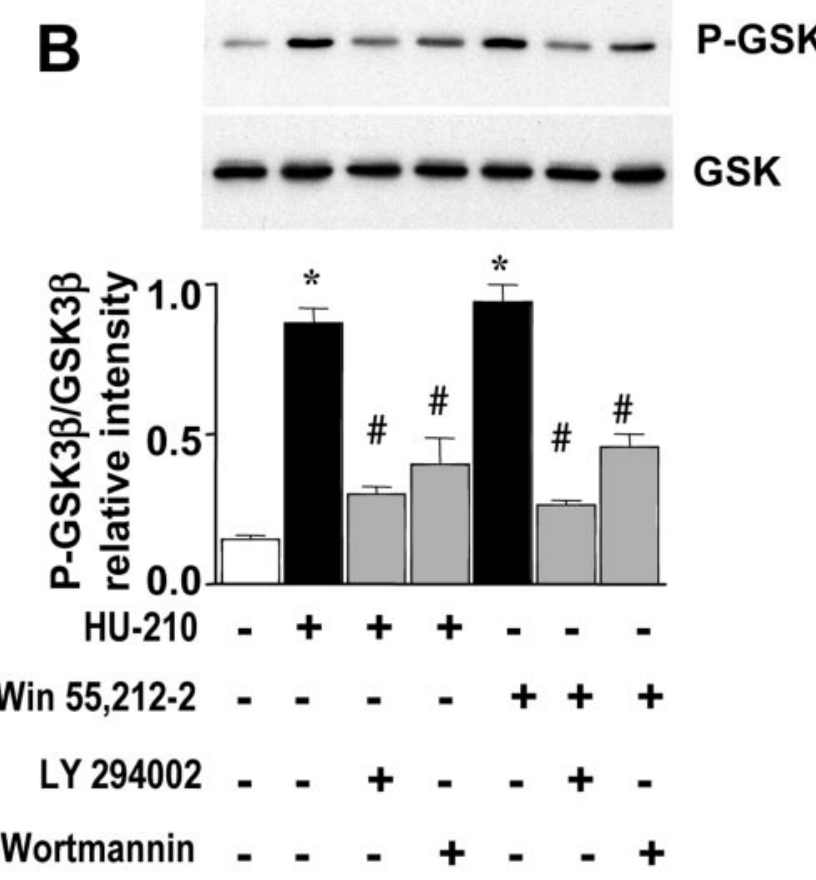

Figure 5. Inhibition of PI3K results in the blockade of cannabinoidinduced phosphorylation of Akt and GSK-3 $\beta$. $A$, Whole-cell lysates were prepared and immunoblotted as described in Materials and Methods with antibodies that recognize phospho-Akt $\left(\mathrm{Ser}^{473}\right)$, phospho-GSK-3 $\beta$ $\left(\mathrm{Ser}^{9}\right)$, and total Akt and GSK-3 $\beta . B$, Oligodendrocyte progenitors were treated for $30 \mathrm{~min}$ with either $100 \mathrm{nM}$ wortmannin or $10 \mu \mathrm{M} \mathrm{LY} 294002$ and then stimulated for $10 \mathrm{~min}$ with the nonselective cannabinoids HU210 $(500 \mathrm{nM})$ and (+)-Win 55,212-2 (25 nM). The densitometric data represent the means \pm SEM of three independent experiments performed in duplicate. ${ }^{*} p<0.001$ versus control untreated cells; $\# p<0.001$ versus HU210- or (+)-Win 55,212-2-stimulated cultures.

in oligodendrocyte progenitor survival (Vemuri and McMorris, 1996; Ebner et al., 2000). This objective was accomplished by immunoblotting whole-cell extracts with phospho-specific antiAkt $\left(\operatorname{Ser}^{473}\right)$ antibody, because phosphorylation of this residue is required for the kinase activity of Akt (Chan et al., 1999). Exposure of progenitors to the nonselective agonists HU210 (500 $\mathrm{nM})$ and (+)-Win 55212-2 (25 nM) or to the selective CB1 agonist ACEA (25 nM) caused a time-dependent phosphorylation of Akt (Fig. $4 A$ ). The three cannabinoids induced a rapid $(5 \mathrm{~min})$ and sustained (60 $\mathrm{min}$ ) phosphorylation of Akt. To determine down- 


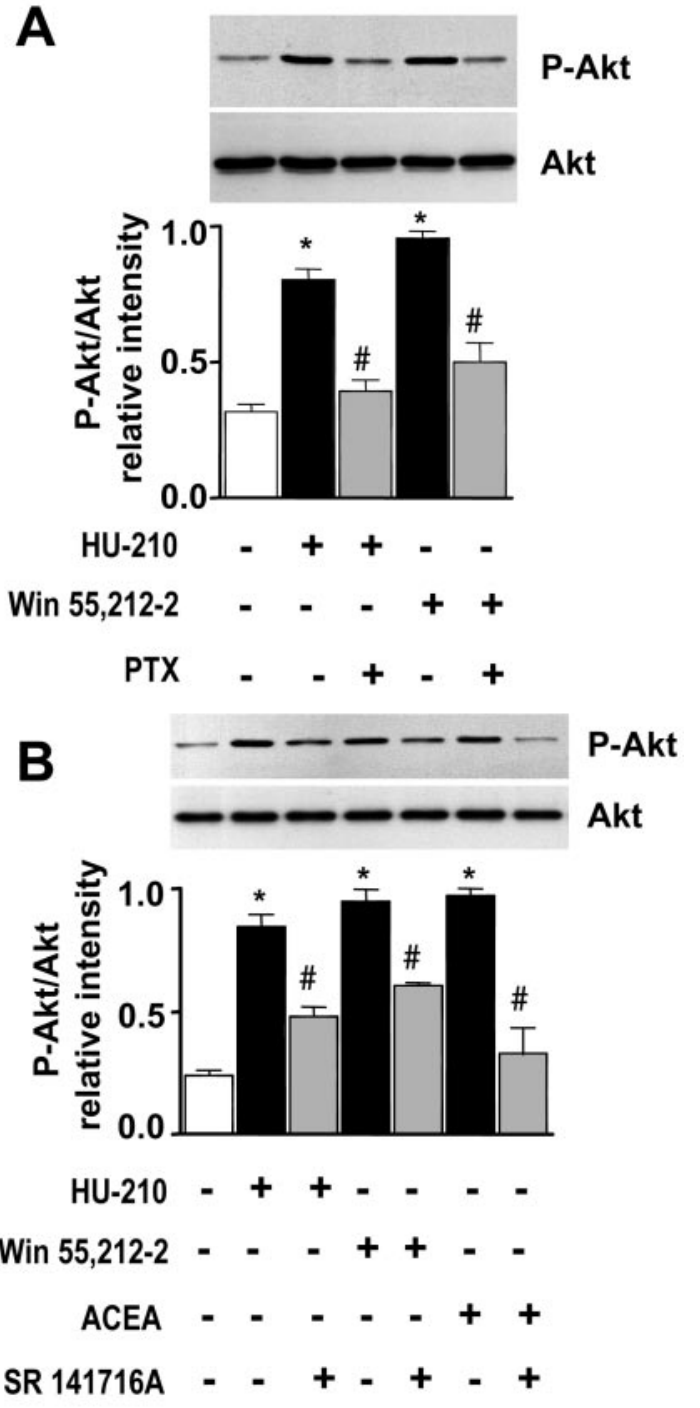

Figure 6. The phosphorylation of Akt in response to cannabinoids is PTX-sensitive and partially dependent on CB1 receptors. Oligodendrocyte progenitors were incubated for $12 \mathrm{hr}$ with $100 \mathrm{ng} / \mathrm{ml}$ pertussis toxin $(A)$ or were pretreated for $50 \mathrm{~min}$ with $1 \mu \mathrm{M}$ of the CB1 receptor antagonist SR141716A, followed by $10 \mathrm{~min}$ of stimulation with the selective CB1 agonist ACEA (20 nM) or with the nonselective cannabinoids HU210 (500 nM) and (+)-Win 55,212-2 (25 nM) (b). Whole-cell lysates were prepared and immunoblotted as described in Materials and Methods with antibodies that recognize phospho-Akt $\left(\mathrm{Ser}^{473}\right)$ and total Akt protein. The densitometric data represent the means \pm SEM of three independent experiments performed in duplicate. $A,{ }^{*} p<0.001$ versus control untreated cells; $\# p<0.001$ versus HU210- or (+)-Win 55,212-2stimulated cultures. $B,{ }^{*} p<0.001$ versus control untreated cells; $\# p<$ 0.001 versus HU210-, (+)-Win 55,212-2-, or ACEA-stimulated cultures.

stream events involved in activated Akt signaling, we focused on GSK- $3 \beta$ because Akt at Ser-9 phosphorylates this enzyme and its phosphorylation inhibits its kinase activity (Cross et al., 1995). We found that stimulation with all three cannabinoids increased Ser-9 phosphorylation of GSK-3 $\beta$ at 10 min (Fig. $4 B$ ).

It is well established that Akt is a downstream target of PI3K. We therefore examined the role of PI3K on cannabinoidmediated Akt activation by pretreating cultures with PI3K inhibitors. The two structurally distinct inhibitors that were used, wortmannin (100 nM) and LY294002 (10 $\mu \mathrm{M})$, significantly re- duced the cannabinoid-induced increases in Akt and GSK-3 $\beta$ phosphorylation (Fig. 5A,B).

Our immunocytochemical, Western blotting, and RT-PCR data demonstrated the presence of $\mathrm{CB} 1$ receptors in oligodendrocyte progenitors, which couple to signal transduction pathways via pertussis toxin (PTX)-sensitive $\mathrm{G}_{\mathrm{i}} / \mathrm{G}_{\mathrm{o}}$-proteins (Pertwee, 1997). To determine whether the stimulatory effect of cannabinoids on $A k t$ is a $G_{i} / G_{o}$ receptor-mediated process, we incubated cells overnight with PTX $(100 \mathrm{ng} / \mathrm{ml})$ before exposure to HU210 $(500 \mathrm{~nm})$ or $(+)$-Win 55212-2 (25 nM). Under these conditions the phosphorylation of Akt stimulated by HU210 or (+)-Win 55212-2 was prevented completely (Fig. 6A). Furthermore, to investigate the involvement of CB1 receptors in cannabinoidinduced Akt phosphorylation, we preincubated the cultures for 50 min with the CB1 receptor-selective antagonist SR141716A (Rinaldi-Carmona et al., 1994). As shown in Figure 6B, the stimulatory effects of HU210 (500 nM) and (+)-Win 55212-2 (25 $\mathrm{nM})$ on Akt phosphorylation were blocked partially by $1 \mu \mathrm{M}$ SR141716A, whereas the CB1 antagonist abolished the effect of ACEA (25 nM). Taken together, these results indicate that cannabinoids, acting on CB1 receptors, are able to activate Akt via PTX-sensitive $G_{i} / G_{o}$-proteins and via a PI3K-dependent signaling pathway.

\section{Promotion of oligodendrocyte progenitor survival by cannabinoids requires PI3K/Akt activity}

Activation of PI3K/Akt mediates cell survival in various cell death paradigms (Brunet et al., 2001). The data presented so far indicate that cannabinoids prevent oligodendrocyte progenitor apoptosis and that these cells express functional cannabinoid receptors linked to a PI3K/Akt signaling pathway. Therefore, to determine whether the survival-promoting effect of cannabinoids requires the PI3K/Akt pathway, we pretreated cells with specific PI3K inhibitors. As shown in Figure $7 A$, oligodendrocyte progenitors cultured for $2 \mathrm{~d}$ in medium with growth factors contained high levels of phosphorylated (activated) Akt. Withdrawal of trophic support resulted in a marked decrease of phospho-Akt steady-state levels, whereas the addition of either HU210 (500 $\mathrm{nm})$ or $(+)$-Win 55212-2 (25 $\mathrm{nm})$ to the cultures during the starvation period promoted a significant recovery of phospho-Akt levels. Phosphorylation of Akt correlated with an increased Akt activity as measured by the increased phosphorylation at Ser-9 of GSK-3 $\beta$, one of its downstream substrates (Fig. 7A). Moreover, inhibition of PI3K with $10 \mu \mathrm{M}$ LY294002 abolished the stimulatory effect of cannabinoids on Akt and GSK-3 $\beta$ phosphorylation (Fig. 7A). Similar results were obtained with $100 \mathrm{~nm}$ wortmannin (data not shown). We next investigated whether the prosurvival effect of cannabinoids is dependent on PI3K/Akt activity. Cell viability was monitored by MTT assay and the quantification of A2B5-positive progenitors. We found that preincubation of cultures with either $10 \mu \mathrm{M}$ LY294002 or $100 \mathrm{nM}$ wortmannin prevented the protection afforded by HU210 (500 nM) and (+)-Win $55212-2(25 \mathrm{nM})$ to oligodendrocyte progenitors (Fig. $7 B$ ).

\section{Possible involvement of $\mathrm{CB} 2$ receptors in the prosurvival action of cannabinoids}

To evaluate the receptor subtype involved in the prosurvival action of cannabinoids, we pretreated starved cultures with the selective CB1 receptor antagonist SR141716A (1 $\mu \mathrm{M})$ before agonist exposure. SR141716A did not block the effects of HU210 or $(+)$-Win 55212-2, whereas it was effective in preventing the survival action of ACEA (Fig. $8 A$ ). We further investigated the 

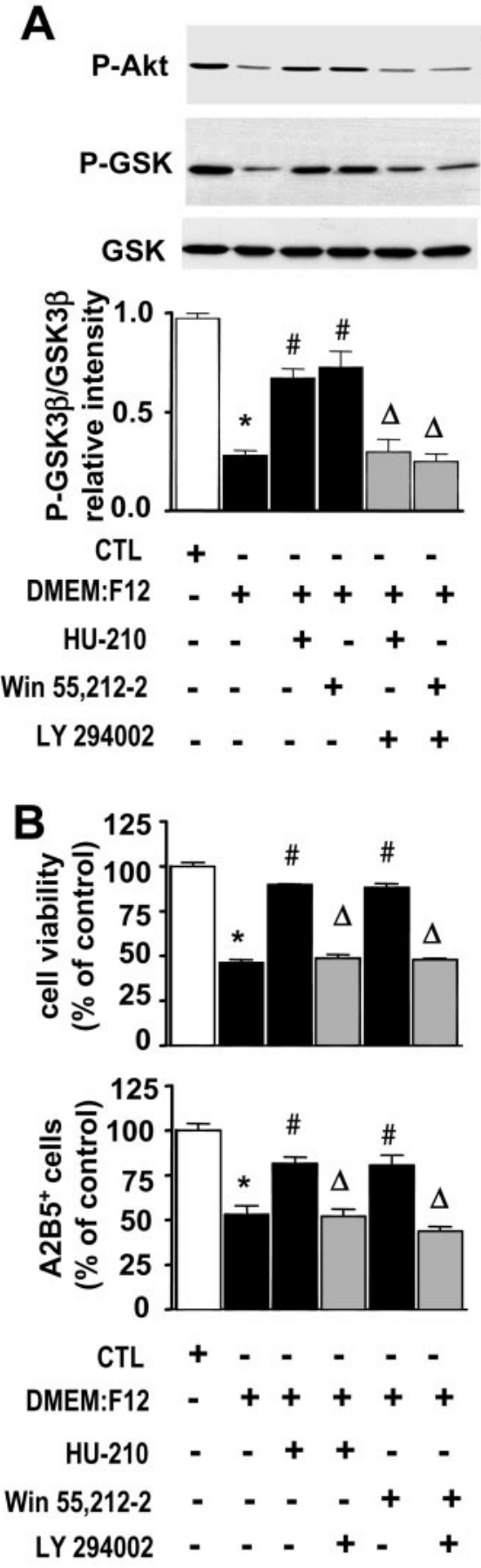

Figure 7. The prosurvival action of cannabinoids in oligodendrocyte progenitors requires PI3K. Oligodendrocyte progenitors were cultured in serum-free defined medium plus $5 \mathrm{ng} / \mathrm{ml} \mathrm{PDGF/bFGF} \mathrm{(controls,} C T L$ ), or cells were switched overnight (12 hr) to DMEM/F12 with or without HU210 (500 nM), (+)-Win 55,212-2 (25 nM), and the PI3K inhibitor LY294002 $(10 \mu \mathrm{M}) . A$, The effect of cannabinoids on Akt and GSK-3 $\beta$ phosphorylation was examined in the presence of LY294002 by Western blot. Whole-cell lysates were prepared and immunoblotted as described in Materials and Methods with antibodies that recognize phospho-Akt $\left(\operatorname{Ser}^{473}\right)$, phospho-GSK-3 $\beta$ (Ser ${ }^{9}$ ), and total GSK-3 $\beta$. The densitometric data of the ratio P-GSK-3 $\beta /$ GSK-3 $\beta$ represent the means \pm SEM of three independent experiments performed in duplicate. $B$, The effect of cannabinoids on oligodendrocyte progenitor survival was established by the MTT assay and by a count of A2B5-positive progenitors. Values are expressed as a percentage of control. The MTT data are the means \pm SEM of four independent experiments performed in triplicate. Quantification of A2B5-positive oligodendrocyte progenitors was obtained from effect of the selective CB2 antagonist SR144528. Interestingly, SR144528 (1 $\mu \mathrm{M})$ did not block the effect of HU210, whereas the coincubation of cultures with both antagonists abolished the prosurvival effect of this cannabinoid (Fig. $8 B$ ). We then examined whether oligodendroglial cells express $\mathrm{CB} 2$ receptor protein. As shown in Figure $9 A$, Western blotting analysis of both cultured progenitors and differentiated oligodendrocytes revealed the presence of a band of $\sim 40 \mathrm{kDa}$ corresponding to the predicted molecular mass of the CB2 receptor (Carlisle et al., 2002). Similarly, positive immunostaining for the $\mathrm{CB} 2$ receptor was found in both cell types (Fig. 9B). Overall, the data that are presented suggest that the protection conferred by cannabinoids after trophic support deprivation involves the activation of the PI3K/Akt signaling pathway and both $\mathrm{CB} 1$ and CB2 cannabinoid receptors.

\section{DISCUSSION}

The present study demonstrates that oligodendrocytes express cannabinoid CB1 receptors in vivo and in culture and provides the first evidence that the activation of these receptors protects oligodendrocyte progenitors from apoptosis produced by deprivation of trophic support via a mechanism dependent on the PI3K/ Akt signaling pathway.

$\mathrm{CB} 1$ receptors were found in high concentrations in relation to neurons. According to the presynaptic and postsynaptic location of neuronal CB1 receptors (Ong and Mackie, 1999), immunoreactivity was concentrated on afferent axon terminals, neuronal cell bodies, and dendrites. The relevant observation in this study was the expression of cannabinoid CB1 receptors by oligodendroglial cells. The presence of CB1 receptors has not been reported previously in individual glial populations in vivo, but expression of CB1 receptors by non-neuronal cells has been detected by immunocytochemistry in light (Moldrich and Wenger, 2000) and electron (Rodríguez et al., 2001) microscope studies. In addition, an "atypical" location of CB1 receptor in white matter in nonneuronal cells and in subventricular zones, where glial proliferation occurs, has been described during rat brain development (Berrendero et al., 1998). Our study reports that cells of the oligodendrocyte lineage express cannabinoid $\mathrm{CB} 1$ receptors at lower levels than neurons. However, CB1 receptor immunoreactivity in the white matter is associated mostly with postnatal and adult brain oligodendrocytes. This agrees with results obtained from the in vitro study. We found that cultured progenitors and differentiated oligodendrocytes expressed CB1 receptor protein and mRNA at higher levels than astrocytes and microglia. Expression of functional cannabinoid receptors in oligodendroglial cells was not explored previously, but cultured astrocytes and microglia are known to express receptors and respond to cannabinoid stimulation (Bouaboula et al., 1995a; Cabral et al., 2001; Molina-Holgado et al., 2002).

Synthetic and endogenous cannabinoids diminish neuronal cell death in models of ischemia or traumatic brain injury (Nagayama et al., 1999; Panikashvili et al., 2001). In culture, cannabinoids reduce the vulnerability of neurons to hypoxia, glucose deprivation, and excitotoxicity (Shen and Thayer, 1998; Nagayama et al., 1999). Together with neurodegenerative diseases, myelin disor-

eight coverslips (5 microscopic fields/coverslip), and results are the means \pm SEM of four independent cultures. ${ }^{*} p<0.001$ versus control cells; $\# p<0.001$ versus cultures deprived of trophic support (DMEM/ F12); $\Delta p<0.001$ versus cultures treated with HU210 or (+)-Win $55,212-2$. 
A

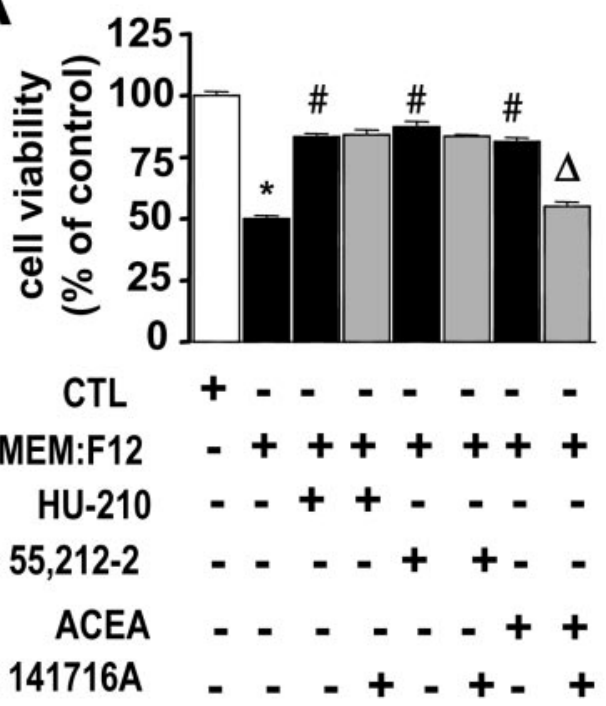

B
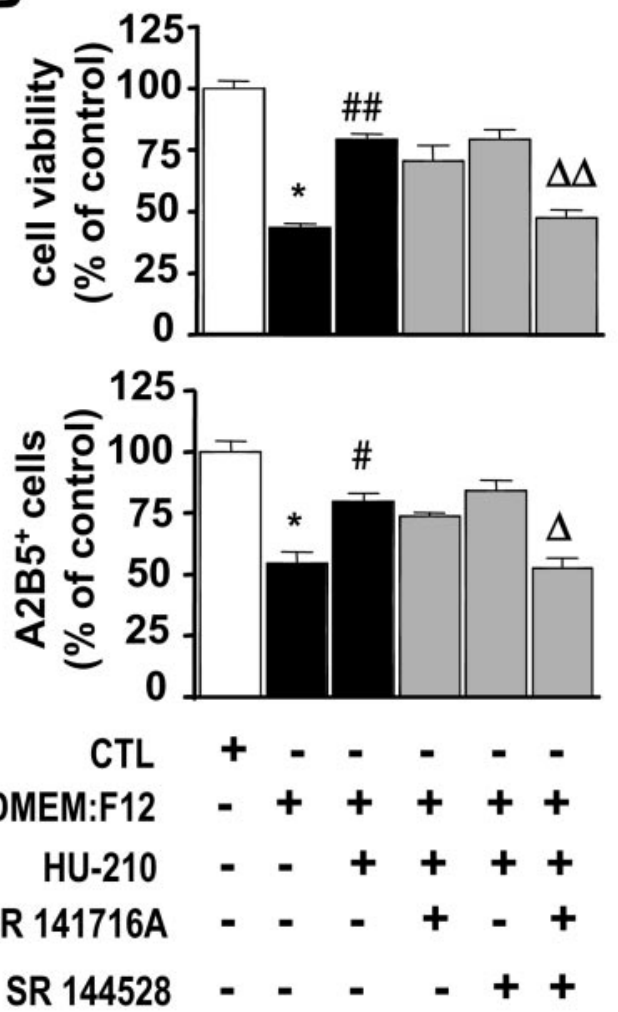

Figure 8. The prosurvival action of cannabinoids is blocked by coincubation with $\mathrm{CB} 1$ and $\mathrm{CB} 2$ receptor antagonists. Oligodendrocyte progenitors were cultured in serum-free defined medium plus $5 \mathrm{ng} / \mathrm{ml} \mathrm{PDGF} /$ bFGF (control, CTL), or cells were switched to DMEM/F12 with or without cannabinoids for $12 \mathrm{hr}$. Cell viability was monitored by MTT assay and by quantification of A2B5-positive oligodendrocyte progenitors. $A$, Effect of the CB1 receptor antagonist SR141716A $(1 \mu \mathrm{M})$ on the protective action of HU210 (500 nM), (+)-Win 55,212-2 (25 nM), or ACEA (20 nM). B, Effects of coincubation of SR141716A (1 $\mu \mathrm{M})$ and the selective CB2 receptor antagonist SR144528 $(1 \mu \mathrm{M})$ on the prosurvival action of HU210 (500 nM). Values are expressed as a percentage of control. The MTT data are the means \pm SEM of four independent experiments performed in triplicate. Quantification of A2B5-positive oligodendrocyte progenitors was obtained from eight coverslips (5 microscopic fields/coverslip), and results are the means \pm SEM of four inde ders affecting oligodendrocytes are among the major CNS pathologies. Oligodendrocytes are highly vulnerable to hypoxiaischemia (Back et al., 2002), oxidative stress (Back et al., 1998), and humoral and cellular immune-mediated attack (Zhou et al., 1998; Molina-Holgado et al., 2001). However, oligodendrocyte progenitors exist in mature CNS and are recruited to demyelinated areas in experimental demyelination and in multiple sclerosis to remyelinate naked axons (Keirstead and Blakemore, 1999; Chang et al., 2000). On this basis, the identification of endogenous signals promoting oligodendrocyte progenitor survival may contribute to developing reparative strategies in demyelinating diseases. Oligodendrocyte progenitors undergo apoptosis in vivo, apparently as a result of a competition for limiting amounts of survival signals (Barres et al., 1992), and in culture after the removal of growth/trophic factors (Barres et al., 1993; Yasuda et al., 1995). Hence in the present study the withdrawal of growth factors and hormones customarily added to the culture medium resulted in a prominent oligodendrocyte progenitor death. Interestingly, trophic deprivation-induced cell death was prevented significantly by cannabinoids. Regarding signaling mechanisms involved in such anti-apoptotic effect, we found that cell death was accompanied by downregulation of the PI3K/Akt signaling pathway and that cannabinoids promoted a significant recovery of Akt activity. In fact, cannabinoids induced Akt phosphorylation in a LY294002- and wortmannin-sensitive manner, and these PI3K inhibitors also blocked the protection conferred by cannabinoids, suggesting that the prosurvival action of cannabinoids depends on PI3K/Akt signaling.

Previous studies have shown a critical role of the PI3K/Akt pathway in oligodendrocyte progenitor survival (Vemuri and McMorris, 1996; Ebner et al., 2000). In this way, expression of a dominant negative form of Akt induces apoptosis of oligodendrocyte progenitors and blocks the protective effects of various survival signals not only after growth factor withdrawal (Flores et al., 2000) but also in TNF- $\alpha$-mediated toxicity (Takano et al., 2000). Indeed, several well known prosurvival factors for oligodendrocyte progenitors such as insulin, PDGF, insulin-like growth factor-I, and others (Barres et al., 1993; Flores et al., 2000) are also strong activators of PI3K/Akt. Therefore, the ability of cannabinoids to activate the prosurvival PI3K/Akt pathway may account for their protective role. Several reports have established that the PI3K/Akt pathway promotes cell survival by both enhancing the expression of anti-apoptotic proteins and inhibiting the activity of proapoptotic ones. Direct intracellular targets of PI3K/Akt involved in the control of apoptosis have been identified in different cell types and include Bad, caspase-9, transcription factors of the Forkhead family, the $\mathrm{I} \kappa \mathrm{B}$ kinase, and GSK-3 $\beta$ (for review, see Brunet et al., 2001). Studies reporting downstream PI3K/Akt signaling in oligodendrocytes are scarce, but an anti-apoptotic role of PI3K/Akt via Bad phosphorylation has been described after growth factor deprivation (Flores et al., 2000; Soane et al., 2001). Here, to determine downstream events involved in PI3K/Akt signaling, we focused on GSK-3 $\beta$. This enzyme is phosphorylated by Akt at Ser-9, and its phosphoryla-

pendent experiments. $A,{ }^{*} p<0.001$ versus control cells; $\# p<0.001$ versus cultures deprived of trophic support (DMEM/F12); $\Delta p<0.001$ versus cultures treated with ACEA. $B,{ }^{*} p<0.001$ versus control cells; $\# p<0.01$ and $\# \# p<0.001$ HU210-treated cells versus cultures deprived of trophic support (DMEM/F12); $\Delta p<0.01$ and $\Delta \Delta p<0.001$ cultures coincubated with CB1 and CB2 antagonists versus HU210-treated cells. 

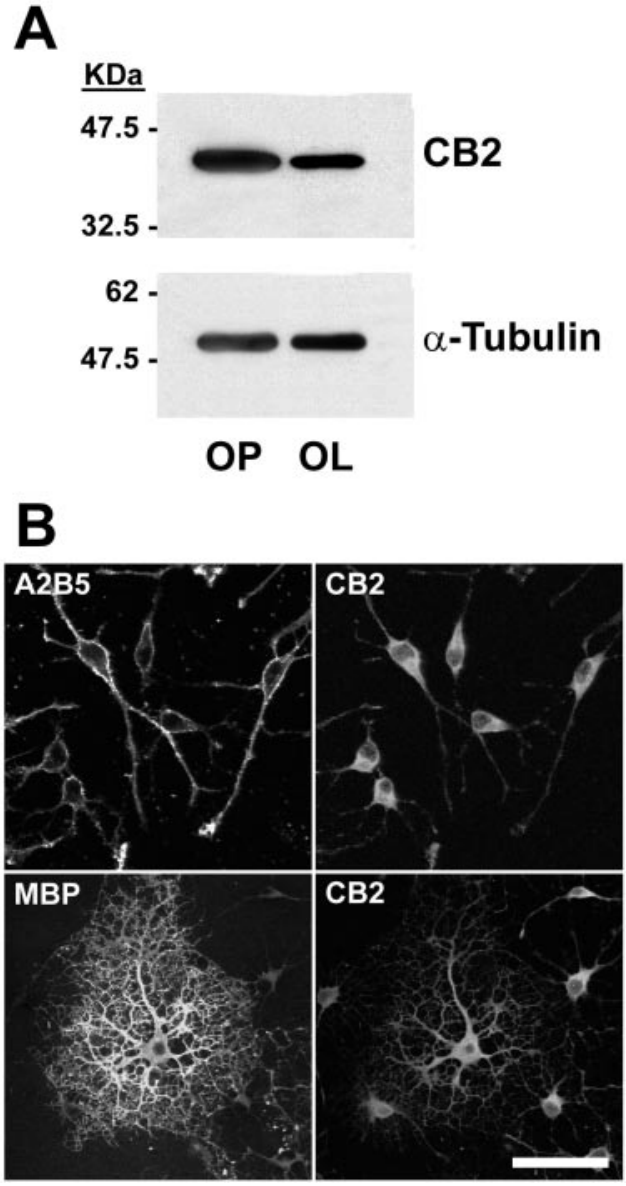

Figure 9. Expression of cannabinoid CB2 receptors in cultured brain glial cells. $A$, The expression of $\mathrm{CB} 2$ receptor protein was demonstrated by Western blot analysis (anti-CB2 diluted to 1:2000) of whole-cell lysates (25 $\mu \mathrm{g}$ of protein). $O P$, Oligodendrocyte progenitors; $O L$, differentiated oligodendrocytes. $B$, The presence of $\mathrm{CB} 2$ receptors in cultured progenitors $\left(\mathrm{A} 2 \mathrm{~B} 5^{+}\right)$and differentiated oligodendrocytes $\left(\mathrm{MBP}^{+}\right)$also was evidenced by immunocytochemistry. Scale bars: A2B5/CB2 (top), $15 \mu \mathrm{m}$; MBP/CB2 (bottom), $30 \mu \mathrm{m}$.

tion inhibits its kinase activity (Cross et al., 1995). We report that cannabinoids increased Akt and GSK-3 $\beta$ phosphorylation and that PI3K inhibitors blocked such effects, thus suggesting that GSK-3 $\beta$ phosphorylation is dependent on upstream Akt activation by PI3K. Although no studies on GSK-3 $\beta$ expression in oligodendrocytes are available, it is known that apoptotic stimuli cause increased activation and nuclear translocation of GSK-3 $\beta$ in different cell types, including neurons (Hetman et al., 2000; Elyaman et al., 2002). In fact, inhibition of GSK-3 $\beta$ activity blocks apoptosis of neurons, whereas overexpression of active GSK-3 $\beta$ or transfection with a GSK-3 $\beta$ mutant that cannot be phosphorylated (inhibited) induces apoptosis (Hetman et al., 2000; Culbert et al., 2001). The nature of GSK-3 $\beta$ effector pathways that are relevant to cell protection remains poorly defined, but it has been proposed that phosphorylation of Tau (Culbert et al., 2001; Elyaman et al., 2002) and of translation initiation factor 2B by active GSK- $3 \beta$ contributes to the control of cell survival, acting upstream of mitochondrial cytochrome $c$ release (Pap and Cooper, 2002). Our results, demonstrating phosphorylation of GSK-3 $\beta$ in a PI3K inhibitor-sensitive manner after protective cannabinoid treatment, are consistent with $\mathrm{PI} 3 \mathrm{~K} / \mathrm{Akt} / \mathrm{GSK}-3 \beta$ prosurvival signaling in oligodendrocyte progenitors.
Based on the use of the selective CB1 agonist ACEA, the experiments in this study indicate that the stimulation of CB1 receptors activate the $\mathrm{PI} 3 \mathrm{~K} / \mathrm{Akt}$ signaling pathway, which results in a prosurvival effect in cultured oligodendrocyte progenitors. Hence the effects of ACEA were abrogated completely by the selective CB1 antagonist SR141716A. Therefore, the presence of active $\mathrm{CB} 1$ receptors and the involvement of $\mathrm{CB} 1$ receptors in the cannabinoid-mediated anti-apoptotic effects in oligodendrocyte progenitors seem clear. However, the effects of the nonselective agonists HU210 and (+)-Win 55212-2 on Akt phosphorylation were inhibited only partially by the $\mathrm{CB} 1$ receptor antagonist SR141716A. Accordingly, the blockage of CB1 receptors alone did not abolish their protective effects. Instead, treatment of the cultures with both SR141716A and the selective CB2 receptor antagonist SR144528 prevented the prosurvival action of cannabinoids. Such pharmacological action of the CB2 receptor antagonist SR144528 is supported by the expression of CB2 receptor protein found in cultured progenitors and differentiated oligodendrocytes. Therefore, these results suggest that, in addition to CB1 receptors, oligodendrocyte progenitors express cannabinoid CB2 receptors for which the stimulation also could be involved in cell survival after deprivation of trophic support. Although unexpected according to the peripheral location of $\mathrm{CB} 2$ receptors, this observation agrees with reports indicating the presence of CB2 receptors in other glial cells. Cultured microglia express CB2 receptors (Carlisle et al., 2002), astrocytes are known to possess G-protein-coupled receptors activated by cannabinoids distinct from the CB1 receptor (Berrendero et al., 1998; Sagan et al., 1999), and the expression of CB2 receptors also has been found in human astrocytomas and in cultured C6 glioma cells (GalveRoperh et al., 2000). In addition, the presence of receptors other than $\mathrm{CB} 1$ or $\mathrm{CB} 2$, tentatively termed $\mathrm{CB} 3$ receptors, which are sensitive to SR141716A and responsive to $(+)$-Win 55212-2 and anandamide, has been postulated recently, thus increasing the cannabinoid receptor heterogeneity (Howlett et al., 2002).

Limited clinical studies have suggested that cannabis might ameliorate the symptomatology in multiple sclerosis patients (Williamson and Evans, 2000), and beneficial effects of synthetic cannabinoids have been reported in vivo in rodent models of multiple sclerosis (Lyman et al., 1989; Achiron et al., 2000; Baker et al., 2000). Apart from their actions on motor and pain pathways, cannabinoids regulate the immune response by reducing the production of inflammatory mediators by leukocytes (Klein et al., 2000), astrocytes (Molina-Holgado et al., 2002), and microglia (Puffenbarger et al., 2000; Cabral et al., 2001), which may contribute to their beneficial effects. The results of the present study also point to a direct role of cannabinoids in promoting the survival of oligodendrocyte progenitors, particularly in unfavorable conditions, as would be the case in demyelinating diseases. Studies in progress are aimed to evaluate the function of cannabinoids in other models affecting oligodendroglial survival.

\section{REFERENCES}

Achiron A, Miron S, Lavie V, Margalit R, Biegon A (2000) Dexanabinol (HU-211) effect on experimental autoimmune encephalomyelitis: implications for the treatment of acute relapses of multiple sclerosis. J Neuroimmunol 102:26-31.

Almazan G, Afar DEH, Bell JC (1993) Phosphorylation and disruption of intermediate filament proteins in oligodendrocyte precursor cultures treated with calyculin A. J Neurosci Res 36:163-172.

Back SA, Gan X, Li Y, Rosenberg PA, Volpe JJ (1998) Maturationdependent vulnerability of oligodendrocytes to oxidative stress-induced death caused by glutathione depletion. J Neurosci 18:6241-6253.

Back SA, Han BH, Lou NL, Chricton CA, Xanthoudakis S, Tam J, Arvin 
KL, Holtzman DM (2002) Selective vulnerability of late oligodendrocyte progenitors to hypoxia-ischemia. J Neurosci 22:455-463.

Baker D, Pryce G, Croxford JL, Brown P, Pertwee RG, Huffman JW, Layward L (2000) Cannabinoids control spasticity and tremor in a multiple sclerosis model. Nature 404:84-87.

Barres BA, Hart IK, Coles HS, Burne JF, Voyvodic JT, Richardson WD, Raff MC (1992) Cell death and control of cell survival in the oligodendrocyte lineage. Cell 70:31-46.

Barres BA, Schmid R, Sendnter M, Raff MC (1993) Multiple extracellular signals are required for long-term oligodendrocyte survival. Development 118:283-295.

Berrendero F, García-Gil L, Hernández ML, Romero J, Cebeira M, de Miguel R, Ramos JA, Fernández-Ruiz JJ (1998) Localization of mRNA expression and activation of signal transduction mechanisms for cannabinoid receptor in rat brain during fetal development. Development 125:3179-3188.

Bouaboula M, Bourrie B, Rinaldi-Carmona M, Shire D, Le Fur G, Casellas P (1995a) Stimulation of cannabinoid receptor CB1 induces krox-24 expression in human astrocytoma cells. J Biol Chem 270:13973-13980.

Bouaboula M, Poinot-Chazel C, Bourrie B, Canat X, Calandra B, Rinaldi-Carmona M, Le Fur G, Casellas P (1995b) Activation of mitogen-activated protein kinases by stimulation of the central cannabinoid receptor CB1. Biochem J 312:637-641.

Breivogel CS, Griffin G, Di Marzo V, Martin BR (2001) Evidence for a new G-protein-coupled cannabinoid receptor in mouse brain. Mol Pharmacol 60:155-163.

Brunet A, Datta SR, Greenberg ME (2001) Transcription-dependent and -independent control of neuronal survival by the PI3K-Akt signaling pathway. Curr Opin Neurobiol 11:297-305.

Cabral GA, Harmon KN, Carlisle SJ (2001) Cannabinoid-mediated inhibition of inducible nitric oxide production by rat microglial cells: evidence for CB1 receptor participation. Adv Exp Med Biol 493:207-214

Carlisle SJ, Marciano-Cabral F, Staab A, Ludwick C, Cabral GA (2002) Differential expression of the CB2 cannabinoid receptor by rodent macrophages and macrophage-like cells in relation to cell activation. Int Immunopharmacol 2:69-82.

Chan TO, Rittenhouse SE, Tsichlis PN (1999) AKT/PKB and other D3 phosphoinositide-regulated kinases: kinase activation by phosphoinositide-dependent phosphorylation. Annu Rev Biochem 68:965-1014.

Chang A, Nishiyama A, Peterson J, Prineas J, Trapp BD (2000) NG2positive oligodendrocyte progenitor cells in adult human brain and multiple sclerosis lesions. J Neurosci 20:6404-6412.

Cross DA, Alessi DR, Cohen P, Andjelkovich M, Hemmings BA (1995) Inhibition of glycogen synthase kinase-3 by insulin mediated by protein kinase B. Nature 378:785-789.

Culbert AA, Brown MJ, Frame S, Hagen T, Cross DA, Bax B, Reith AD (2001) GSK-3 inhibition by adenoviral FRAT1 overexpression is neuroprotective and induces Tau dephosphorylation and $\beta$-catenin stabilization without elevation of glycogen synthase activity. FEBS Lett 507:288-294

Devane WA, Hanus L, Breuer A, Pertwee RG, Stevenson LA, Griffin G, Gibson D, Mandelbaum A, Etinger A, Mechoulam R (1992) Isolation and structure of a brain constituent that binds to the cannabinoid receptor. Science 258:1946-1949.

Ebner S, Dunbar M, McKinnon RD (2000) Distinct roles for PI3K in proliferation and survival of oligodendrocyte progenitor cells. J Neurosci Res 62:336-345.

Elyaman W, Terro F, Wong NS, Hugon J (2002) In vivo activation and nuclear translocation of phosphorylated glycogen synthase kinase- $3 \beta$ in neuronal apoptosis: links to tau phosphorylation. Eur J Neurosci 15:651-660.

Fernandez PA, Tang DG, Cheng L, Prochiantz A, Mudge AW, Raff MC (2000) Evidence that axon-derived neuregulin promotes oligodendrocyte survival in the developing rat optic nerve. Neuron 28:81-90.

Flores AI, Mallon BS, Matsui T, Ogawa W, Rosenzweig A, Okamoto T, Macklin WB (2000) Akt-mediated survival of oligodendrocytes induced by neuregulins. J Neurosci 20:7622-7630.

Galve-Roperh I, Sánchez C, Cortés ML, Gómez del Pulgar T, Izquierdo M, Guzmán M (2000) Antitumoral action of cannabinoids: involvement of sustained ceramide accumulation and extracellular signalregulated kinase activation. Nat Med 6:313-319.

Gard AL, Burrell MR, Pfeiffer SE, Rudge JS, Williams IIWC (1995) Astroglial control of oligodendrocyte survival mediated by PDGF and leukemia inhibitory factor-like protein. Development 121:2187-2197.

Gómez del Pulgar T, Velasco G, Guzman M (2000) The CB1 cannabinoid receptor is coupled to the activation of protein kinase $\mathrm{B} / \mathrm{Akt}$. Biochem J 347:369-373.

Gu C, Cassacia-Bonnefil P, Srinivasan A, Chao MV (1999) Oligodendrocyte apoptosis mediated by caspase activation. J Neurosci 19:3043-3049.

Hanus L, Abu-Lafi S, Fride E, Breuer A, Vogel Z, Shalev DE, Kustanovich I, Mechoulam R (2001) 2-Arachidonyl glyceryl ether, an endoge- nous agonist of the cannabinoid $\mathrm{CB}_{1}$ receptor. Proc Natl Acad Sci USA 98:3662-3665.

Herkenham M, Lynn AB, Johnson MR, Melvin LS, de Costa BR, Rice KC (1991) Characterization and localization of cannabinoid receptors in rat brain: a quantitative in vitro autoradiographic study. J Neurosci 11:563-583.

Hetman M, Cavanaugh JE, Kimelman D, Xia Z (2000) Role of glycogen synthase kinase- $3 \beta$ in neuronal apoptosis induced by trophic withdrawal. J Neurosci 20:2567-2574.

Howlett AC, Barth F, Bonner TI, Cabral G, Casellas P, Devane WA, Felder CC, Herkenham M, Mackie K, Martin BR, Mechoulam R, Pertwee RG (2002) International Union of Pharmacology. XXVII. Classification of cannabinoid receptors. Pharmacol Rev 54:161-202.

Huang CC, Lo SW, Hsu KS (2001) Presynaptic mechanism underlying cannabinoid inhibition of excitatory synaptic transmission in rat striatal neurons. J Physiol (Lond) 532:731-748.

Keirstead HS, Blakemore WF (1999) The role of oligodendrocytes and oligodendrocyte progenitors in CNS remyelination. Adv Exp Med Biol 468:183-197.

Klein TW, Lane B, Newton CA, Friedman H (2000) The cannabinoid system and cytokine network. Proc Soc Exp Biol Med 225:1-8.

Lassmann H (1998) Neuropathology in multiple sclerosis: new concepts. Mult Scler 4:93-98.

Levine JM, Reynolds R, Fawcett JW (2001) The oligodendrocyte precursor cell in health and disease. Trends Neurosci 24:3947.

Lyman WD, Sonett JR, Brosnan CF, Elkin R, Bornstein MB (1989) Delta-9-tetrahydrocannabinol: a novel treatment for experimental autoimmune encephalomyelitis. J Neuroimmunol 23:73-81.

Mailleux P, Vanderhaeghen JJ (1992) Distribution of neuronal cannabinoid receptor in the adult rat brain: a comparative receptor-binding radioautography and in situ hybridization histochemistry. Neuroscience 48:655-668.

Matsuda LA, Lolait SJ, Brownstain MJ, Young AC, Bonner TI (1990) Structure of a cannabinoid receptor and functional expression of the cloned cDNA. Nature 346:561-564.

Matsuda LA, Bonner TI, Lolait SJ (1993) Localization of cannabinoid receptor mRNA in rat brain. J Comp Neurol 327:535-550.

McCarthy KD, de Vellis J (1980) Preparation of separate astroglial and oligodendroglial cell cultures from rat cerebral tissue. J Cell Biol 85:890-902.

Mechoulam R, Ben-Shabat S, Hanus L, Ligumsky M, Kaminski NE, Schatz AR, Gopher A, Almog S, Martin BR, Compton DR, Pertwee RJ, Griffin G, Bayewitch M, Barg, J Vogel Z (1995) Identification of an endogenous 2-monoglyceride, present in canine gut, that binds to cannabinoid receptors. Biochem Pharmacol 50:83-90.

Moldrich G, Wenger T (2000) Localization of the CB1 cannabinoid receptor in the rat brain. An immunohistochemical study. Peptides 21:1735-1742.

Molina-Holgado E, Vela JM, Arévalo-Martín A, Guaza C (2001) LPS/ IFN- $\gamma$ cytotoxicity in oligodendroglial cells: role of nitric oxide and protection by the anti-inflammatory cytokine IL-10. Eur J Neurosci 13:493-502.

Molina-Holgado F, Molina-Holgado E, Guaza C, Rothwell NJ (2002) Role of CB1 and CB2 receptors in the inhibitory effects of cannabinoids on lipopolysaccharide-induced nitric oxide release. J Neurosci Res 67:829-836.

Munro S, Thomas KL, Abu-Shaar M (1993) Molecular characterization of a peripheral receptor for cannabinoids. Nature 365:61-65.

Nagayama T, Sinor AD, Simon RP, Chen J, Graham SH, Jin K, Greenberg DA (1999) Cannabinoids and neuroprotection in global and focal cerebral ischemia and in neuronal cultures. J Neurosci 19:2987-2995.

Ong WY, Mackie K (1999) A light and electron microscopic study of the CB1 cannabinoid receptor in primate brain. Neuroscience 92:1177-1191.

Panikashvili D, Simeonidou C, Ben-Shabat S, Hanus L, Breuer A, Mechoulam R, Shohami E (2001) An endogenous cannabinoid (2AG) is neuroprotective after brain injury. Nature 413:527-531.

Pap M, Cooper GM (2002) Role of translation initiation factor 2B in control of cell survival by the phosphatidylinositol 3-kinase/Akt/glycogen synthase kinase $3 \beta$ signaling pathway. Mol Cell Biol 22:578-586.

Pertwee RG (1997) Pharmacology of cannabinoid CB1 and CB2 receptors. Pharmacol Ther 74:129-180.

Pertwee RG (2001) Cannabinoid receptors and pain. Prog Neurobiol 63:569-611.

Puffenbarger RA, Boothe AC, Cabral GA (2000) Cannabinoids inhibit LPS-inducible cytokine mRNA expression in rat microglial cells. Glia 29:58-69.

Rinaldi-Carmona M, Barth F, Heaulme M, Shire D, Calandra B, Congy C, Martinez S, Maruani J, Neliat G, Caput D, Ferrara P, Soubrié P, Brelière JC, Le Fur G (1994) SR141716A, a potent and selective antagonist of the brain cannabinoid receptor. FEBS Lett 350:240-244.

Rodríguez JJ, Mackie K, Pickel VM (2001) Ultrastructural localization of the CB1 cannabinoid receptor in $\mu$-opioid receptor patches of the rat caudate putamen nucleus. J Neurosci 21:823-833.

Sagan S, Venance L, Torrens Y, Cordier J, Glowinski J, Giaume C (1999) 
Anandamide and WIN 55212-2 inhibit cyclic AMP formation through G-protein-coupled receptors distinct from CB1 cannabinoid receptors in cultured astrocytes. Eur J Neurosci 11:691-699.

Shen M, Thayer SA (1998) Cannabinoid receptor agonists protect cultured rat hippocampal neurons from excitotoxicity. Mol Pharmacol $54: 459-462$.

Soane L, Cho H-J, Niculescu F, Rus H, Shin ML (2001) C5b-9 terminal complement complex protects oligodendrocytes from death by regulating Bad through phosphatidylinositol 3-kinase/Akt pathway. J Immunol 167:2305-2311.

Takano R, Hisahara S, Namikawa K, Kiyama H, Okano H, Miura M (2000) Nerve growth factor protects oligodendrocytes from tumor necrosis factor- $\alpha$-induced injury through Akt-mediated signaling mechanism. J Biol Chem 275:16360-16365.

van der Stelt M, Veldhuis WB, van Haaften GW, Fezza F, Bisogno T, Bär PR, Veldink GA, Vliegenthart JFG, Di Marzo V, Nicolay K (2001)
Exogenous anandamide protects rat brain against acute neuronal injury in vivo. J Neurosci 21:8765-8771.

Vela JM, González B, Castellano B (1998) Understanding glial abnormalities associated with myelin deficiency in the jimpy mutant mouse. Brain Res Rev 26:29-42.

Vemuri GS, McMorris FA (1996) Oligodendrocytes and their precursors require phosphatidylinositol 3-kinase signaling for survival. Development 122:2529-2537.

Williamson EM, Evans FJ (2000) Cannabinoids in clinical practice. Drugs 60:1303-1314.

Yasuda T, Grinspan J, Stern J, Franceschini B, Bannerman P, Pleasure D (1995) Apoptosis occurs in the oligodendroglial lineage and is prevented by basic fibroblast growth factor. J Neurosci Res 40:306-317.

Zhou L, Trapp BD, Miller RH (1998) Demyelination in the central nervous system mediated by an anti-oligodendrocyte antibody. J Neurosci Res 54:158-168. 